\title{
36. RESULTS OF DSDP LEG 26 AND THE GEOLOGIC HISTORY OF THE SOUTHERN INDIAN OCEAN'
}

\author{
Bruce P. Luyendyk, ${ }^{2}$ Woods Hole Oceanographic Institution, Woods Hole, Massachusetts \\ and \\ Thomas A. Davies, Scripps Institution of Oceanography, La Jolla, California
}

\begin{abstract}
Leg 26 of the Deep Sea Drilling Project in the southern Indian Ocean was planned to investigate: (1) the history of the Southwest Branch of the Indian Ocean Ridge and the history of the crust and oceanic sedimentation in that general area; (2) the history of the Ninetyeast Ridge; (3) the origin and history of Broken RidgeNaturaliste Plateau; and (4) the oldest sediment in the Indian Ocean and the date of the breakup of Gondwanaland. Most of these objectives were met.

Crustal ages in the southwest Indian Ocean span the Cretaceous. Pelagic sedimentation has occurred intermittently here until the Miocene when a western boundary undercurrent constrained by the Southwest Branch brought terrigenous materials south into the Mozambique Basin and prevented sedimentation in the Madagascar Basin. The Southwest Branch is spreading at $0.9 \mathrm{~cm} / \mathrm{yr}$ north northeast and is no older than middle Eocene based on extrapolation of this rate. The carbonate compensation depth in the southwest Indian Ocean has been shallower than its present depth during the Late Cretaceous and Miocene.

Sites on the Ninetyeast Ridge range in age from Eocene-Oligocene to Late Cretaceous and become progressively older to the north. This suggests that the ridge belongs to the Indian plate. The stratigraphy consists of pelagic calcareous sediments overlying shallow-water and littoral volcanic sequences. Because sites to the north can be shown to be the same age as the Indian plate, some of the ridge formed near or on the crest of the ancient Southeast Branch of the Indian Ocean Ridge. The origin of the ridge can be modeled as a combination point volcanic source construction and a leaky transform fault.

Broken Ridge was a shallow marine carbonate platform in the Late Cretaceous. It was uplifted above sea level in the Eocene as a result of rifting and uplift of the Southeast Branch which split Broken Ridge from Kerguelen Plateau. Since then Broken Ridge has subsided and accumulated pelagic carbonates. The Naturaliste Plateau is older than middle Albian. It received detrital sediments until the Late Cretaceous and pelagic carbonates since then. Erosion has removed large sections of the Tertiary from the plateau. Basement under both features is unknown, but the drilling results suggest that these structures are marine and volcanic (oceanic) in origin.

The Wharton Basin is oldest in the south, and formed during north-south spreading, at about $6 \mathrm{~cm} / \mathrm{yr}$, which began about 130 m.y.B.P. These observations indicate that India separated from Antarctica rather than from Western Australia. Potassium-argon dating of basalt from Site 257 in the southeastern Wharton Basin indicates that there is an intrabasalt unconformity and that the lower basalt unit is possibly as old as Early Jurassic.

Regional unconformities centered on the Oligocene, early Tertiary, and Late Cretaceous can be recognized in the Indian Ocean Basin. These unconformities are expressed either as a true disconformity or are implied by the existence of dissolution facies which
\end{abstract}

'Woods Hole Oceanographic Institution Contribution No. 3363.

${ }^{2}$ Now at Department of Geological Sciences, University of California, Santa Barbara, California. 
resulted in zeolitic clay, deposited at very slow rates (condensed series). The well-documented Oligocene hiatus is best developed as a disconformity in the western Indian Ocean, in the southwest Pacific, and on the Ninetyeast Ridge. At places in the eastern Indian Ocean it is a dissolution facies. This distribution pattern suggests that the hiatus is due to the flow of Antarctic Bottom Water which developed as a strong western boundary undercurrent and is related to glacial conditions in Antarctica.

Sedimentation since the Late Cretaceous in the Indian Ocean Basin has been normally pelagic. This regime has been strongly modified at various times by bottom water circulation. Volcanic activity has affected sedimentation in limited areas.

\section{INTRODUCTION}

The Indian Ocean is the smallest of the three major ocean basins but appears to be geologically the most complex. The major physiographic features are shown in Figure 1. The principal features of the Indian Ocean have been described by Laughton et al. (1971). The dominant feature is the active mid-ocean ridge system which has the form of an inverted Y. The Southeast Branch of the ridge joins with the Pacific-Antarctic Ridge. Sea-floor spreading from this ridge has separated Australia from Antarctica since the Eocene. The Southwest Branch is less well known and appears to be much more complex, being cut by many northnortheast-trending fracture zones.

An interesting feature of the Indian Ocean is the occurrence of many aseismic ridges and plateaus. The most striking of these is the Ninetyeast Ridge which extends along the $90^{\circ} \mathrm{E}$ meridian from $32^{\circ} \mathrm{S}$ to the Bay of Bengal. Ninetyeast Ridge has been shown by deep-sea drilling to have a shallow water, volcanic origin, but other aseismic features, e.g., Broken Ridge, Kerguelen Plateau, have been regarded as continental fragments left behind as the surrounding continents separated. Despite several drilling attempts, the origin of many of these features remains obscure.

In contrast to the relatively simple opening of the north and south Atlantic, the formation of the Indian Ocean is believed to have followed a very complicated history. Relative movements between five lithospheric plates-Africa, Antarctica, Madagascar, India, and Australia-have taken place since the mid-Mesozoic. The concept of Gondwanaland, or the ancient form of the Indian Ocean continents, is well known. However, the history of how these continents were broken off and separated to form the Indian Ocean is poorly known and speculative. McKenzie and Sclater (1971) used Cenozoic marine magnetic anomalies to reconstruct the relative positions of the plates belonging to the Indian Ocean system at various times since the Late Cretaceous. Because the earth's magnetic field is believed not to have reversed during the later part of the Cretaceous (Larson and Pitman, 1972), magnetic stripes or isochrons for this period do not exist, and plate motions cannot be determined by magnetic charting of the sea floor. However, the results of deep-sea drilling do permit some reconstruction of pre-Tertiary plate movements. This is discussed in detail in a following chapter (Luyendyk, this volume, Chapter 37).
The distribution of sediment thickness in the Indian Ocean has been described by Ewing et al. (1969). Their results, based on extensive study of seismic reflection records, are shown in Figure 2a. The major thickness of sediment is found in the Ganges and Indus cones and in the basins off the east coast of Africa. The controlling influence of physiography on sediment distribution is clearly shown. The southern part of the Central Indian Basin is virtually devoid of sediment because of its isolated position, as is the western side of the Wharton Basin. The sediment thicknesses revealed by deep-sea drilling (Figure $2 b$ ) agree with the inferences from reflection profiling, in a general way. Many of the obvious differences can be related to the deliberate selection of drilling sites in atypical locations.

Sclater et al. (1971) have shown that there is an empirical relationship between depth and age of the oceanic crust. This can be accounted for by the thermal contraction of the cooling lithosphere as sea-floor spreading moves it away from the spreading center. The curves developed by Sclater et al. (1971) from geophysical evidence can be extended by adding the results from deep-sea drilling and the resultant sinking curve used in reconstructing paleobathymetry (Berger and von Rad, 1972; Pimm, 1974). Such a sinking curve for the Indian Ocean is shown in Figure 3. Points which lie a long way from the curve are those from areas which are clearly not typical ocean crust, e.g., Ninetyeast Ridge.

The Indian Ocean south of $20^{\circ} \mathrm{S}$ is considerably less well known than the more northerly part. The Leg 26 drilling program was planned to investigate four distinct problem areas:

1) The history of the Southwest Branch of the Indian Ocean Ridge and the history of the crust and oceanic sedimentation in that general region (Sites 250, 251, 252);

2) The nature and history of the Ninetyeast Ridge (Sites 253, 254);

3) The age, nature and history of Broken RidgeNaturaliste Plateau, supposed microcontinents (Sites $255,258)$;

4) The oldest sediment in the Indian Ocean and thus possibly the date of the initial breakup of Gondwanaland (Sites 256, 257).

Furthermore, in traversing the southern Indian Ocean, Leg 26 touched on the perimeters of regional investigations carried out by Leg 25 in the west and Legs 22 and 27 in the east. Consequently, the results of Leg 26 extend and amplify the results of these other cruises. 


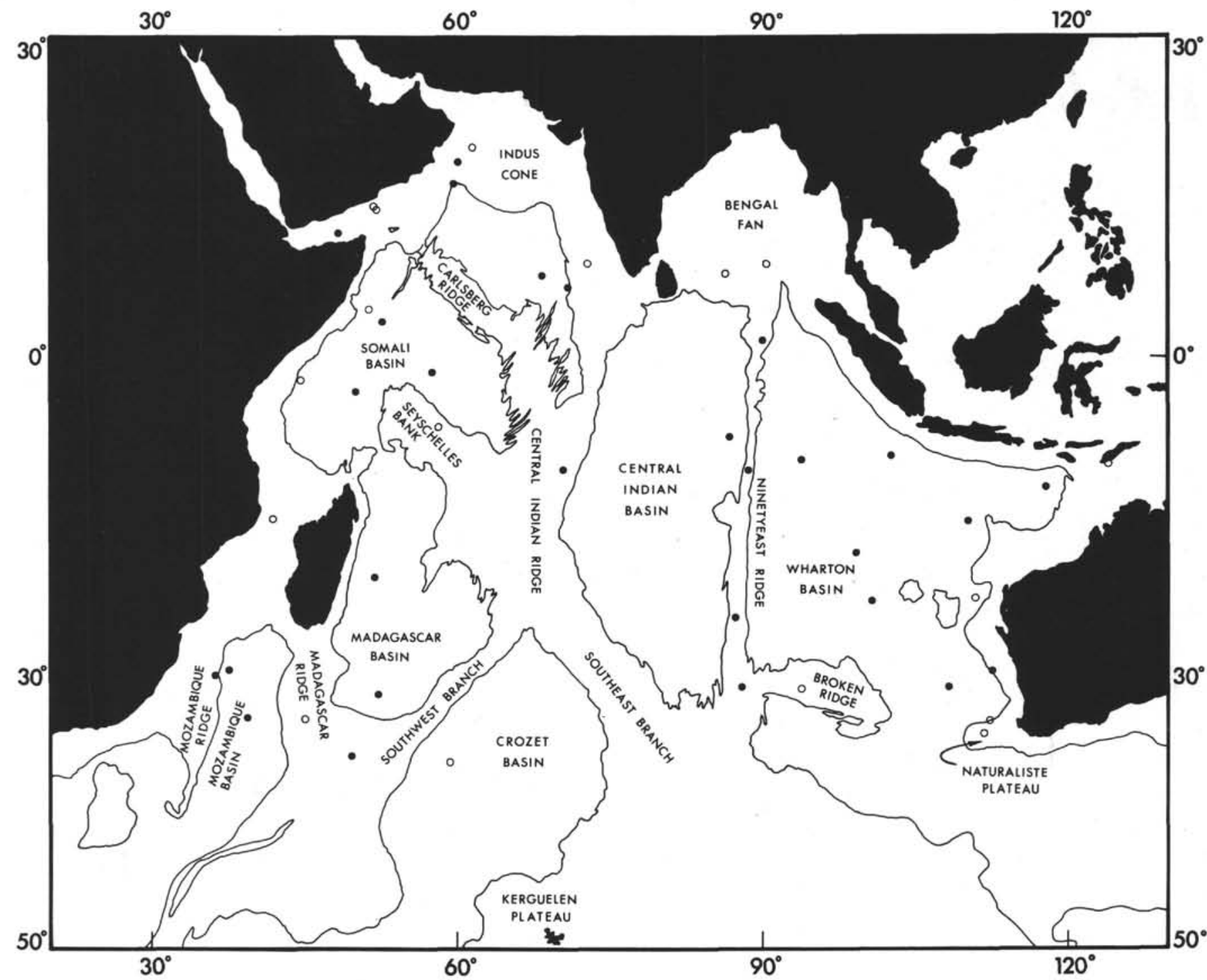

Figure 1. Principal physiographic features of the Indian Ocean as defined by the 4000-meter contour. Deep Sea Drilling Project sites which reached basement are shown as solid dots; other sites as open circles.

A sedimentological problem of oceanwide proportions which was coming into focus near the Leg 26 planning stage was the possible existence of a deep-sea unconformity or dissolution facies centered on the Oligocene. This phenomenon was observed in the western Pacific (Kennett et al., 1972); equatorial Indian Ocean (von der Borch, Sclater, et al., 1974); and western Indian Ocean (Simpson, Schlich, et al., in press). Does this unconformity extend to the areas of Leg 26 sites? Besides this question, it could also be asked whether the Late Cretaceous-Paleocene unconformity observed in the Pacific (Douglas et al., 1973) could also be observed in the Indian Ocean. Leg 26 was well suited to examine this possibility since many sites were planned in crust believed to be of Late Cretaceous or older age.

Figure 4 shows the track of Glomar Challenger and the sites drilled in the Indian Ocean. Details of the sites drilled on Leg 26 are presented in Table 1, and summarized graphically in a large chart at the back of this book. In this contribution we summarize the results of Leg 26 drilling in each of the four problem areas and try to integrate these results with other knowledge about each region. Emphasis is placed on the history and processes of sedimentation, but results of tectonic significance are also discussed. The question of oceanwide unconformities and dissolution facies is then addressed, and finally a first attempt is made to put the results of deep-sea drilling into the broader context of the history of sedimentation in the southern Indian Ocean.

\section{SOUTHWESTERN INDIAN OCEAN (SITES 250, 251, 252)}

\section{General}

The dominant feature of the southwestern Indian Ocean is the Southwest Branch of the Indian Ocean Ridge. The southwest Branch is believed to be an active- 


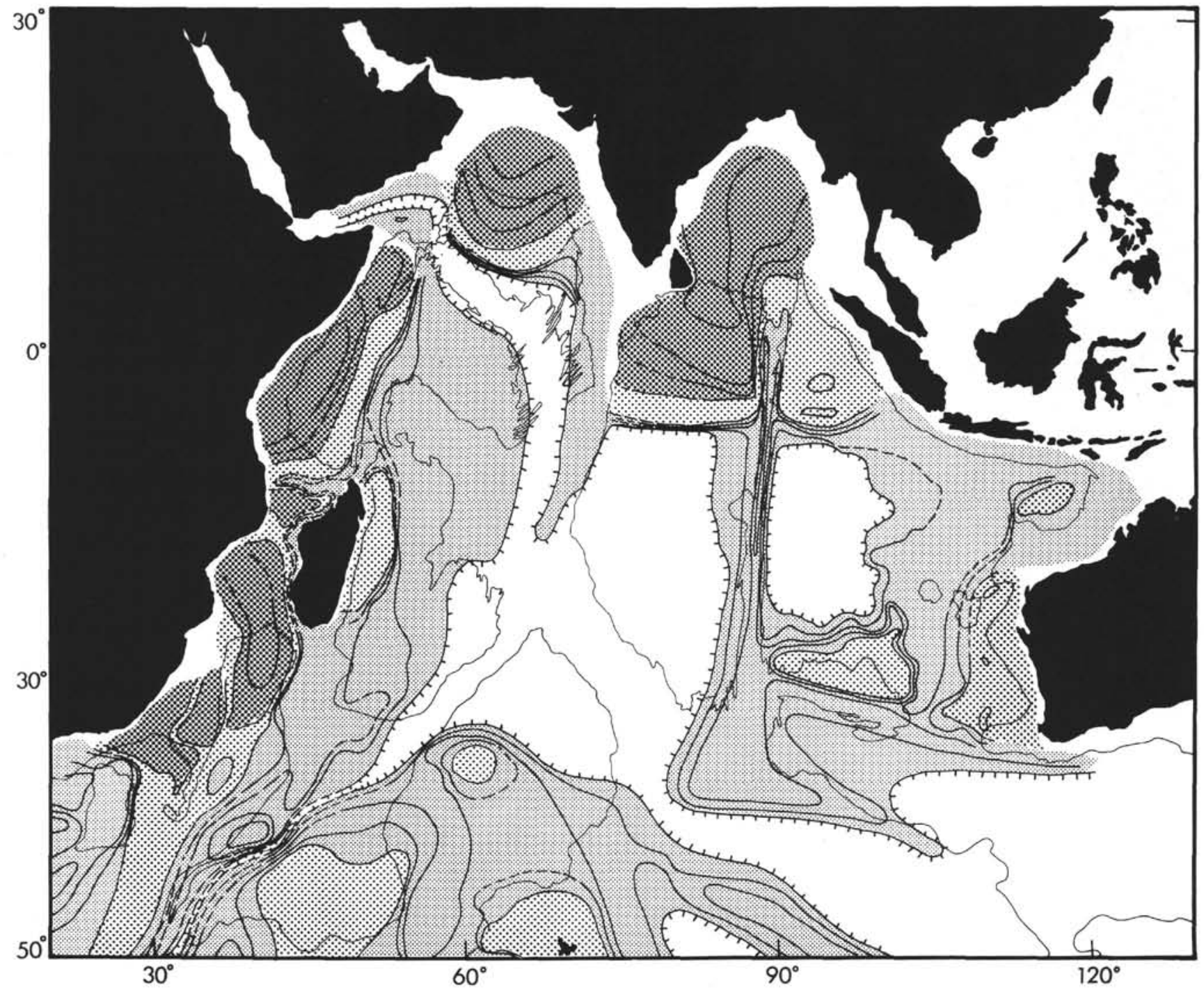

Figure 2a. Sediment thickness in the Indian Ocean as defined by seismic reflection records (modified from Ewing et al., 1969). Blank = less than $0.1 \mathrm{sec}$ of sediment; light stipple $=0.1-0.5 \mathrm{sec} ;$ coarse stipple $=0.5-1.0 \mathrm{sec}$; heavy stipple $=$ greater than $1.0 \mathrm{sec}$.

TABLE 1

Summary of Holes Drilled on Leg 26

\begin{tabular}{|c|c|c|c|c|c|c|c|c|c|}
\hline \multirow[b]{2}{*}{ Hole } & \multicolumn{2}{|c|}{ Position } & \multirow[b]{2}{*}{ Dates of Drilling } & \multirow{2}{*}{$\begin{array}{c}\text { Water } \\
\text { Depth } \\
\text { (m) }\end{array}$} & \multirow{2}{*}{$\begin{array}{l}\text { Pene- } \\
\text { tration } \\
(\mathrm{m})\end{array}$} & \multirow{2}{*}{$\begin{array}{l}\text { No. } \\
\text { Cores } \\
\text { Cut }\end{array}$} & \multirow{2}{*}{$\begin{array}{c}\text { Total } \\
\text { Cored } \\
\text { (m) }\end{array}$} & \multirow{2}{*}{$\begin{array}{c}\text { Total } \\
\text { Recovered } \\
\text { (m) }\end{array}$} & \multirow{2}{*}{$\begin{array}{c}\text { Recovery } \\
\text { (\%) }\end{array}$} \\
\hline & Latitude & Longitude & & & & & & & \\
\hline 250 & $33^{\circ} 27.74^{\prime} \mathrm{S}$ & $39^{\circ} 22.15^{\prime} \mathrm{E}$ & 9-10 Sept 1972 & 5119 & 65.0 & 3 & 28.0 & 21.45 & 77 \\
\hline $250 \mathrm{~A}$ & $33^{\circ} 27.74^{\prime} \mathrm{S}$ & $39^{\circ} 22.15^{\prime} \mathrm{E}$ & 11-14 Sept 1972 & 5119 & 738.5 & 26 & 240.5 & 124.4 & 52 \\
\hline 251 & $36^{\circ} 30.26^{\prime} \mathrm{S}$ & $49^{\circ} 29.08^{\circ} \mathrm{E}$ & 17-18 Sept 1972 & 3489 & 87.5 & 10 & 87.5 & 67.2 & 77 \\
\hline $251 \mathrm{~A}$ & $36^{\circ} 30.26^{\prime} \mathrm{S}$ & $49^{\circ} 29.08^{\prime} \mathrm{E}$ & $18-21$ Sept 1972 & 3489 & 499.0 & 31 & 276.5 & 158.38 & 57 \\
\hline 252 & $37^{\circ} 02.44^{\prime} \mathrm{S}$ & $59^{\circ} 14.33^{\prime} \mathrm{E}$ & 23-24 Sept 1972 & 5032 & 247.0 & 7 & 57.0 & 41.5 & 73 \\
\hline 253 & $24^{\circ} 52.65^{\prime} \mathrm{S}$ & $87^{\circ} 21.97^{\prime} \mathrm{E}$ & 1-5 Oct 1972 & 1962 & 559.0 & 58 & 536.5 & 270.1 & 50.3 \\
\hline 254 & $30^{\circ} 58.15^{\prime} \mathrm{S}$ & $87^{\circ} 53.72^{\prime} \mathrm{E}$ & $7-9$ Oct 1972 & 1253 & 343.5 & 38 & 329.0 & 150.5 & 45.7 \\
\hline 255 & $31^{\circ} 07.87^{\prime} \mathrm{S}$ & $93^{\circ} 43.72^{\prime} \mathrm{E}$ & $11-12$ Oct 1972 & 1144 & 108.5 & 11 & 99.0 & 7.9 & 8 \\
\hline 256 & $23^{\circ} 27.35^{\prime} \mathrm{S}$ & $100^{\circ} 46.46^{\prime} \mathrm{E}$ & $15-17$ Oct 1972 & 5361 & 270.0 & 11 & 99.0 & 78.4 & 79 \\
\hline 257 & $30^{\circ} 59.16^{\prime} \mathrm{S}$ & $108^{\circ} 20.99^{\prime} \mathrm{E}$ & 20-23 Oct 1972 & 5278 & 326.5 & 17 & 155.5 & 76.7 & 49 \\
\hline 258 & $33^{\circ} 47.69^{\prime} \mathrm{S}$ & $112^{\circ} 28.42^{\prime} \mathrm{E}$ & $25-28$ Oct 1972 & 2793 & 525.0 & 25 & 230.5 & 115.55 & 50 \\
\hline $258 \mathrm{~A}$ & $33^{\circ} 47.69^{\prime} \mathrm{S}$ & $112^{\circ} 28.42^{\prime} \mathrm{E}$ & 28-29 Oct 1972 & 2793 & 123.5 & 9 & 85.5 & 65.5 & 77 \\
\hline Total & & & & & 3893 & 246 & 2224.5 & 1177.7 & 53 \\
\hline
\end{tabular}




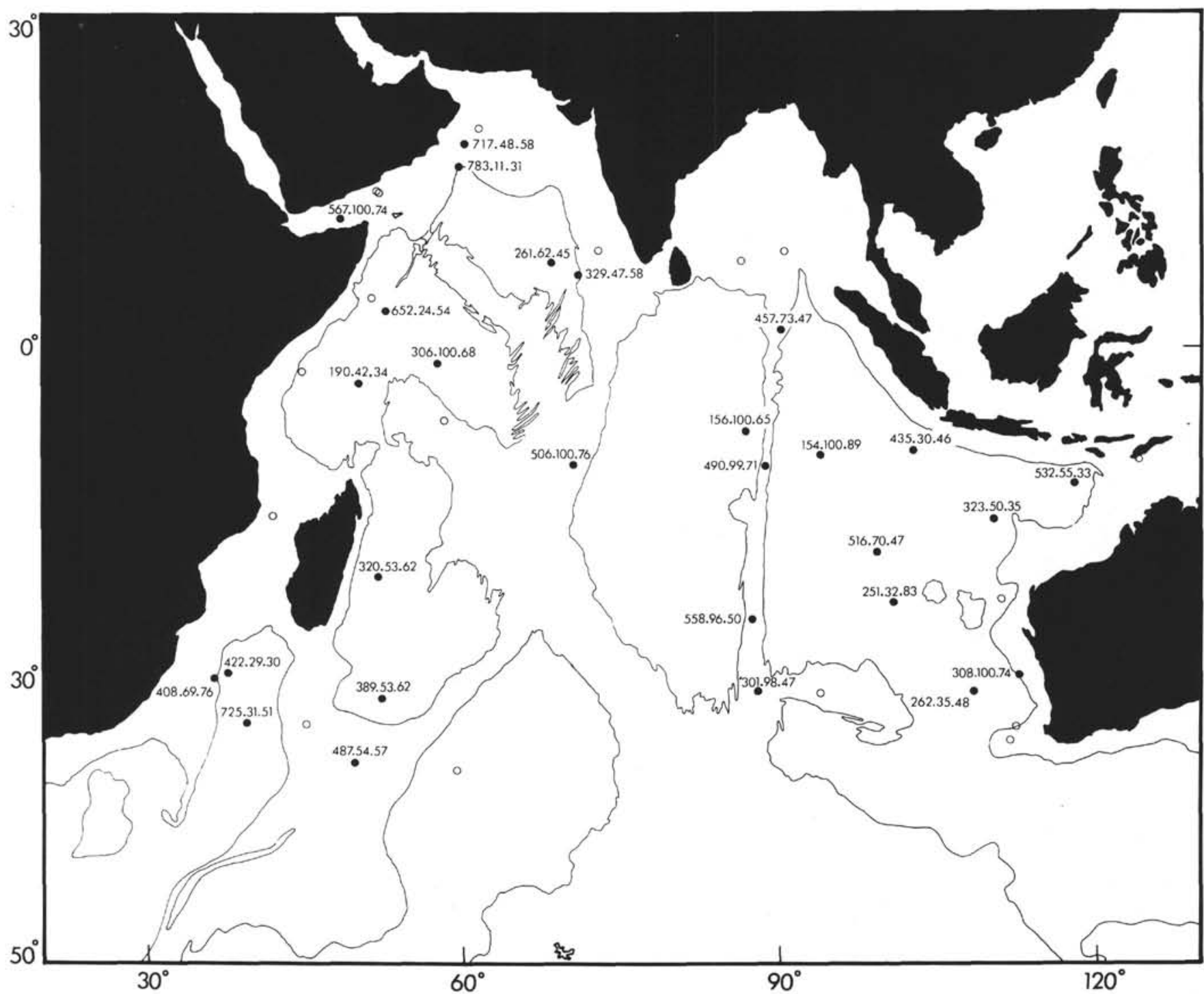

Figure 2b. Sediment thickness in the Indian Ocean as shown by drilling. The three numbers by each site which reached basement are sediment thickness in meters, percentage of section cored, and percentage of cored section recovered.

ly spreading oceanic ridge, on the basis of evidence from earthquake epicenters (Barazangi and Dorman, 1969); sediment distribution (Ewing et al., 1969); and topography (Heezen and Tharp, 1965). The ridge structure trends northeast and is offset in the left lateral sense by several major north-northeast-trending fracture zones such as the Mozambique, Prince Edward, and Malagasy fractures (Heezen and Tharp, 1965; Schlich and Patriat, 1968, 1971).

The spreading rate and the age of the Southwest Branch are not known. Schlich and Patriat (1971), Berg (1971), and McKenzie and Sclater (1971) have calculated rates from identification of magnetic anomalies of $0.6-1.0 \mathrm{~cm} / \mathrm{yr}$ in a northerly direction. However, the magnetic data over the ridge are extremely noisy and these calculations are therefore in doubt. McKenzie and Sclater (1971) have suggested that the Southwest Branch began actively spreading sometime between 20 and 35 m.y. ago. If this is true then the tectonic history of the western Indian Ocean becomes con- siderably more complicated because the latest episode of spreading on the Carlsberg and Central Indian ridges began 36 m.y. ago (op. cit. and results of Hole 238, Leg 24 [Fisher, Bunce, et al., 1972]). An age of 40-50 m.y. has been suggested by Schlich (in press).

The sea floor on either side of the Southwest Branch, in the Mozambique and Crozet basins, is considerably older, having been formed in earlier episodes of spreading, possibly from an ancient Southeast Branch, before the initiation of the Southwest Branch as a spreading center (McKenzie and Sclater, 1971). The Mozambique Basin has a depth near $4.5 \mathrm{~km}$ and is bounded on the west and east by the north-southtrending Mozambique and Madagascar ridges, respectively. Sediment thickness in the Mozambique Basin varies from 0.5 to $1.5 \mathrm{sec}$ DT (Ewing et al., 1969). Much of this sediment is thought to have been derived from the Zambezi Canyon and Fan system which transports sediments from East Africa and Madagascar south to the Mozambique Basin. Evidence exists for the 


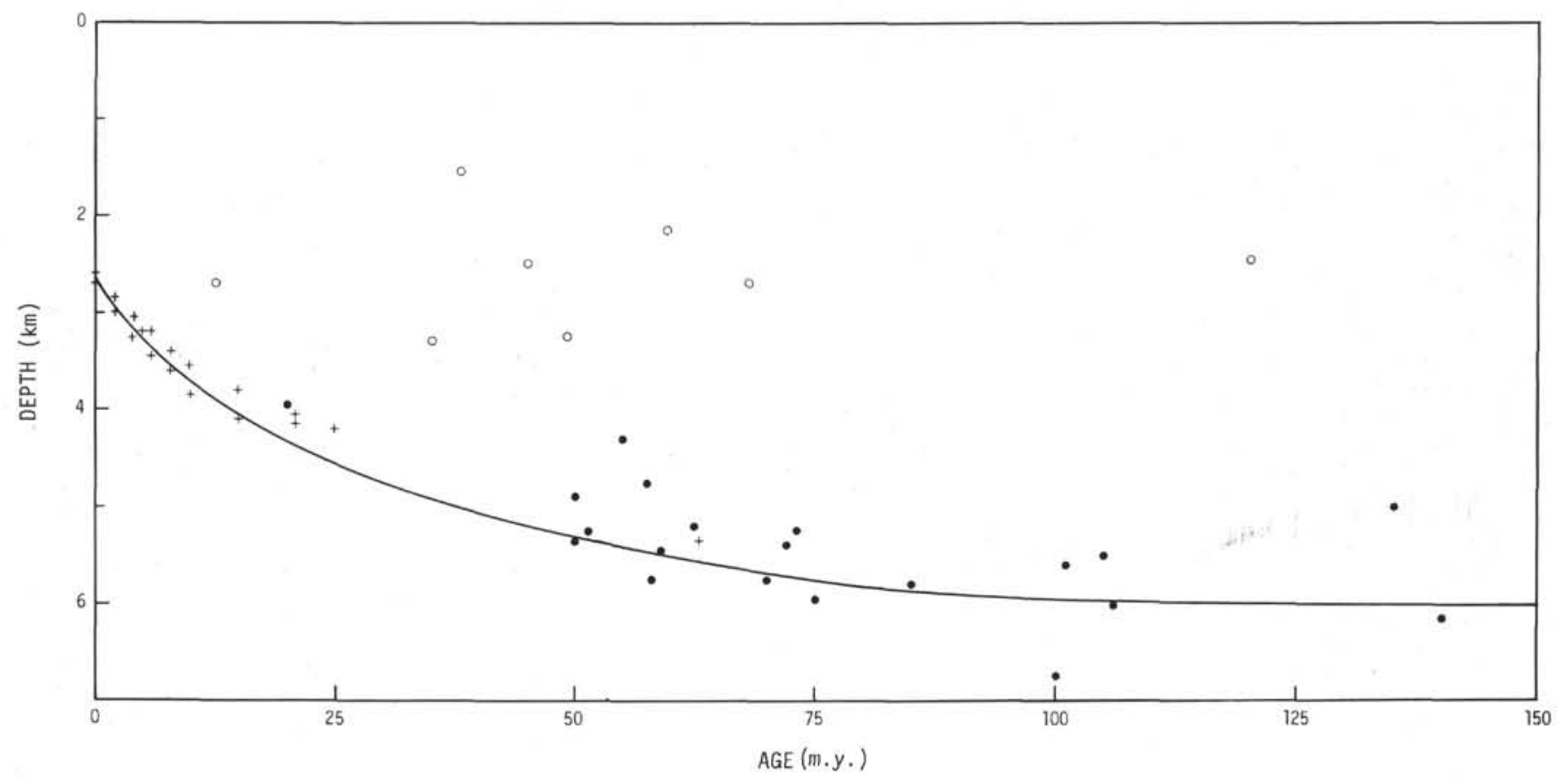

Figure 3. Age/depth curve for the Indian Ocean. Crosses = geophysical date from Sclater et al., 1971; solid dots = Deep Sea Drilling Project basement ages from "normal" oceanic crust; open circles = Deep Sea Drilling Project "basement" ages from obviously anomalous regions (e.g., Ninetyeast Ridge, etc.).

redistribution of these sediments in the basin by bottom currents, with clockwise flow, which travel north along the east scarp of the Mozambique Ridge, east across the Zambezi Fan, and then flow south along the west edge of the Madagascar Ridge (Heezen and Hollister, 1971). Bottom photographs show ripple marks on the east side of the basin (Heezen and Hollister, 1971) and seismic profiles show dune-like sedimentary structures here (Ewing et al., 1969). The Crozet Basin is about $5 \mathrm{~km}$ deep and bounded on the north by the two branches of the Indian Ocean Ridge. The branches of the Indian Ocean Ridge are effective barriers to bottom circulation, hence we might expect the sediments of the Crozet Basin to be unlike those of the basins to the north.

\section{Drilling Results}

\section{Site 250 (Mozambique Basin)}

Site 250 is on the southeast side of the Mozambique Basin (Figure 5) and was selected to date the crust in an area apparently devoid of magnetic anomalies. Two holes were drilled to a maximum penetration of 738.5 meters. Olivine basalt, assumed to be basement, was reached 725.3 meters below the seabed. The contact between the basalt and the overlying sediment appears to be depositional, rather than intrusive and extrapolation from the oldest datable sediments, 15 meters above basalt, gives an age of Late Cretaceous (Coniacian) or older for the basalt. This extrapolation is verified by a radiometric age determination of $89 \pm 6$ m.y. (Cenomanian-Coniacian) for the basalt (Rundle et al., this volume, Chapter 17). Five lithologic units can be recognized in the overlying sedimentary section (see Figure 6). The uppermost three units (Unit 2 is subdivided) make up the larger part of the sedimentary section and consist of detrital sediments and coccolith ooze. Unit 4 is entirely brown detrital clay. The top of Unit 4 is early Miocene in age, whereas the bottom of the unit is Coniacian. The middle of the unit is unfossiliferous, but it seems probable that there is a major disconformity in this unit between Cretaceous and Miocene sediments. The bottom part of Unit 4 shows extensive bioturbation and abundant zeolites, authigenic overgrowths on the clay minerals and development of siderite, rather than pyrite, as the predominant iron mineral. The basal sediment, Unit 5, is 16.5 meters of gray detrital clay. The Miocene and Cretaceous parts of the section are essentially devoid of calcareous fossils. Those nannofossils which are found in the Cretaceous part of the section are heavily etched and may be reworked. The Miocene part of the section contains reworked Oligocene and Eocene fossils throughout and shallow-water foraminifera in the uppermost part (Unit 2b). Sediment accumulation rates are high, $47 \mathrm{~m} / \mathrm{m} . \mathrm{y}$. for the lower Pliocene-Recent part of the section, and lower for the Miocene $(25 \mathrm{~m} / \mathrm{m} . \mathrm{y}$.) and Cretaceous parts of the section.

\section{Site 251 (Southwest Branch)}

Site 251 is located about $180 \mathrm{~km}$ north of the Southwest Branch of the Indian Ocean Ridge (Figure 5). Sediments at the site consist of nannoplankton ooze and chalk and can be divided into six units and subunits 


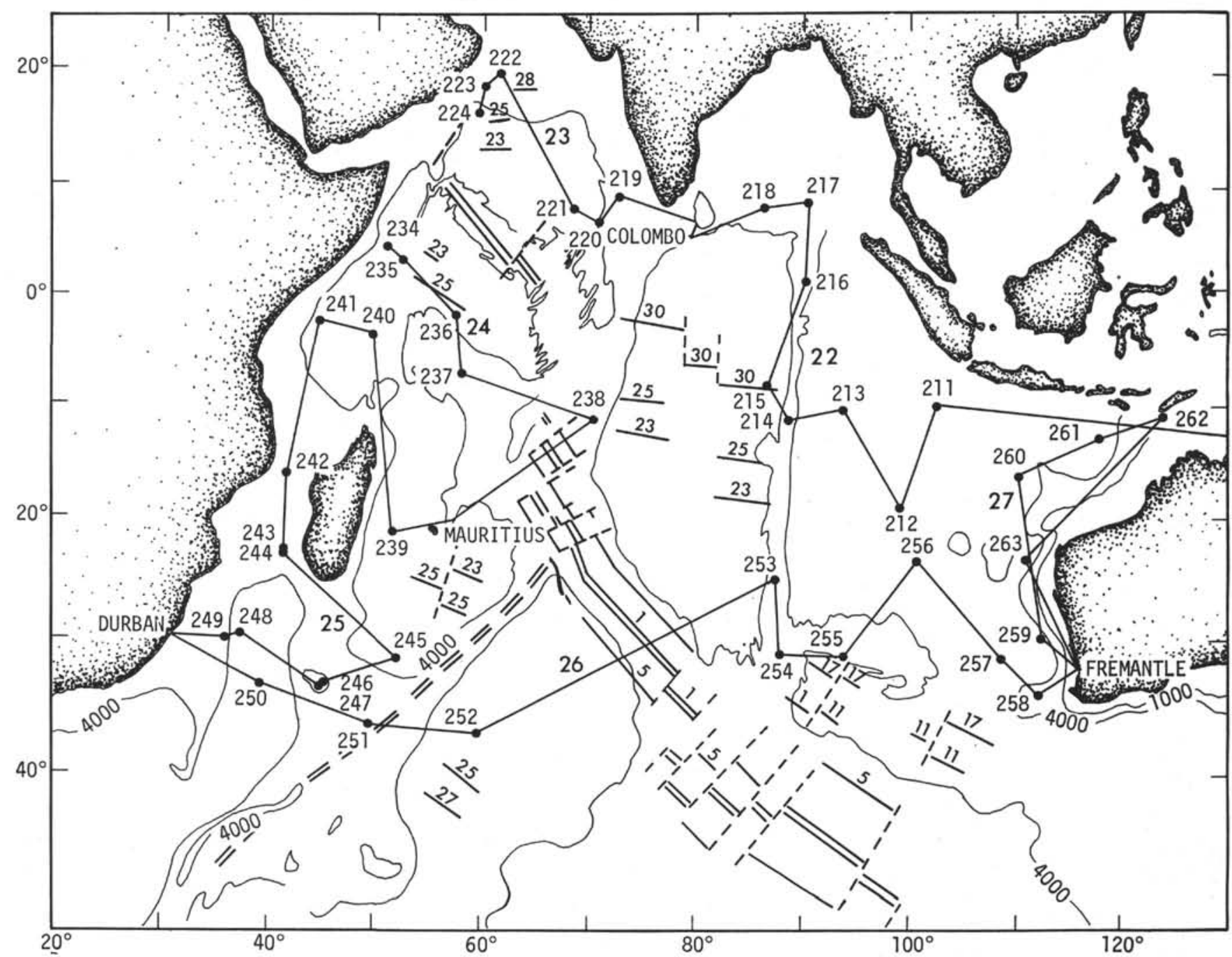

Figure 4. Localities of Deep Sea Drilling Project Sites 211 through 263 (Legs 22-27) in the Indian Ocean. Base chart is from McKenzie and Sclater (1971).

(Figure 6). The lowermost part of the sedimentary section is remarkable for containing abundant authigenic garnet. As near as can be determined, the sediments lie conformably on the basal basalt. A pocket of nannofossil ooze found in the basalt gives an age between 17 and $18 \mathrm{~m} . \mathrm{y}$. (early Miocene) for the top of this unit. Radiometric age determinations give an age of $39 \pm 2$ m.y. (latest Eocene) for the basalt (Rundle et al., this volume, Chapter 17); however, the reliability of this determination is in doubt because of possible contamination by atmospheric argon (Kempe, this volume, Chapter 14). Site 251 is of biostratigraphic interest because an almost complete uninterrupted midlatitudinal Neogene sequence, from early Miocene to Recent, was recovered. However, strong dissolution effects are evident in the Miocene section with a concomitant decrease in abundance of the less robust forms an an increase in benthonic foraminiferal content. A good correspondence is found between zonations based on foraminifera and nannoplankton. The nannoplankton can be correlated with published zonations in other areas, but the foraminiferal zonation established in tropical areas cannot be directly applied to the mid-latitude succession at this site. Sedimentation rates at the site are fairly uniform ranging between 29 and 32 $\mathrm{m} / \mathrm{m} . \mathrm{y}$. An apparent abrupt decrease in this rate to about $13 \mathrm{~m} / \mathrm{m} . \mathrm{y}$. was measured in the early Pliocene.

\section{Site 252 (Crozet Basin)}

Site 252 is located in the northwest Crozet Basin, off the southern flank of the Southwest Branch of the Indian Ocean Ridge (Figure 5). Hole 252 was drilled to 247 meters before deteriorating weather conditions forced abandonment of the site. The oldest sediment sampled, at 247 meters, is late Miocene in age, on the basis of the radiolarians. The recovered section is mainly radiolarian clay which can be divided into two units: Unit 1, of Quaternary age, is 4 meters of brown radiolarian clay, and Unit 2 , from 5 to 247 meters subbottom, is an olive-gray diatom-bearing radiolarian clay of Quaternary to late Miocene age. This unit owes its coloration to a few percent of finely disseminated pyrite. 


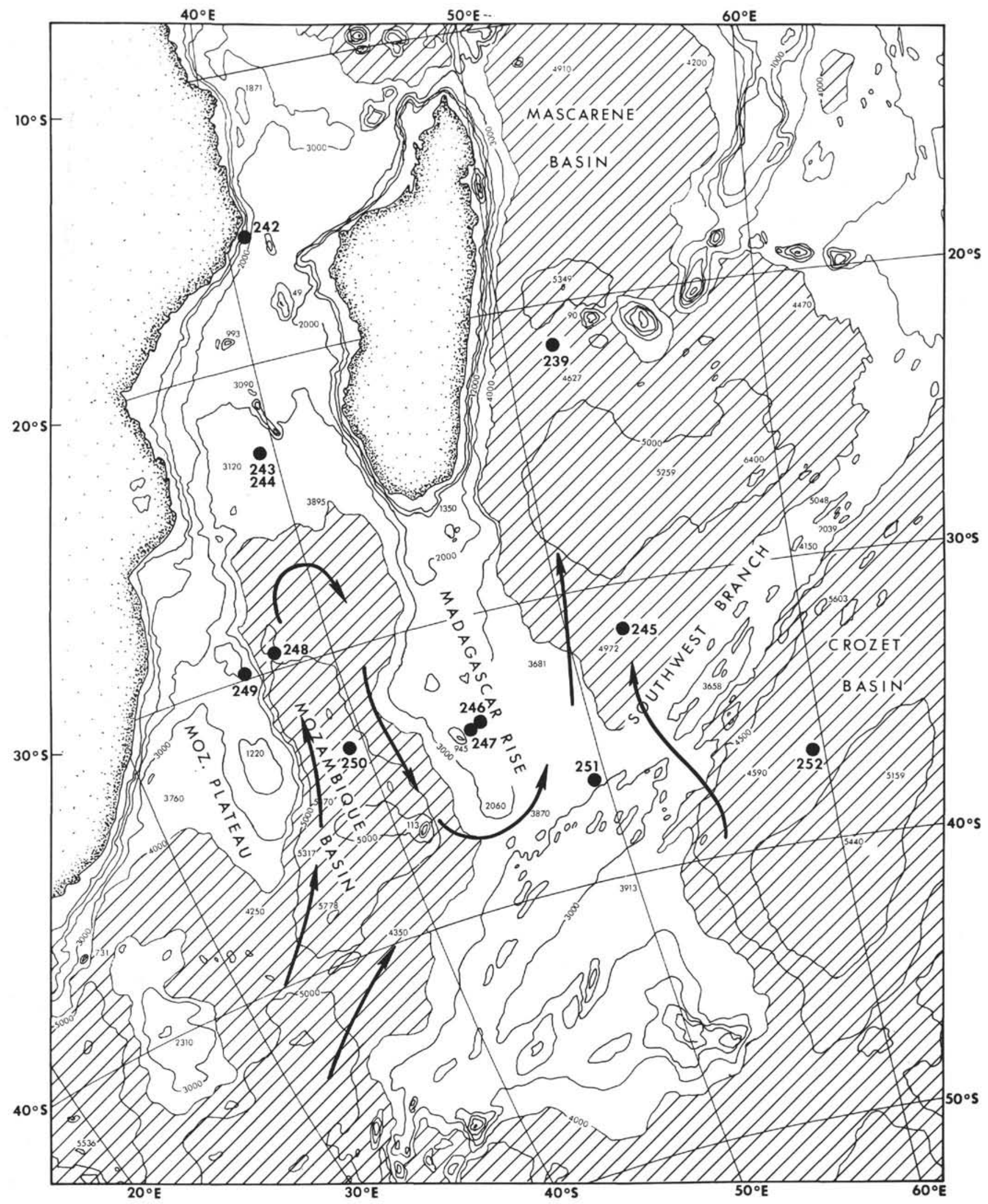

Figure 5. Bathymetry of the southwest Indian Ocean showing drilling sites and bottom water circulation. 


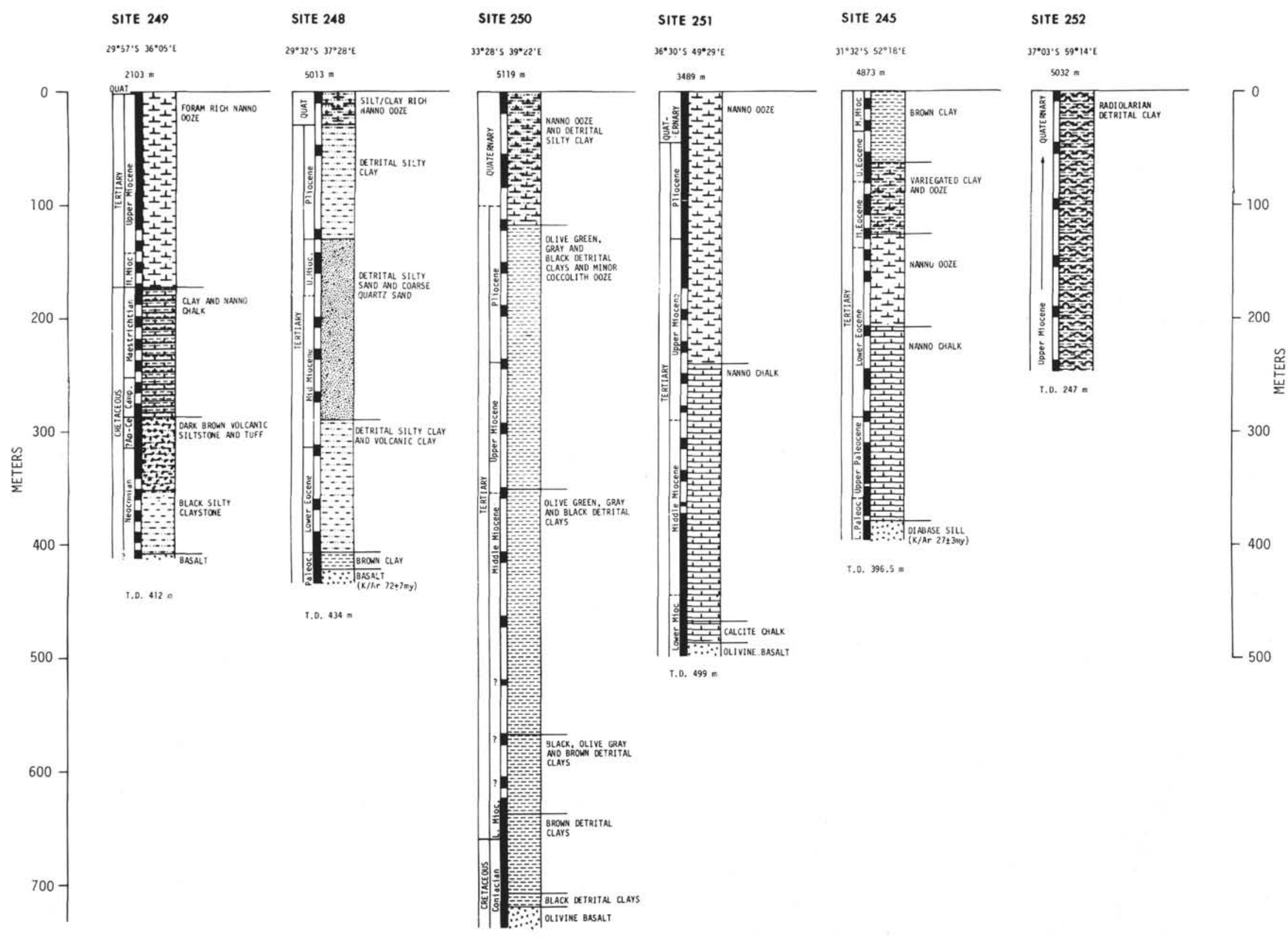


With the exception of Unit 1, calcareous microfossils are virtually absent in this section. Radiolaria are abundant and well preserved throughout the entire section. The value of this radiolarian section is diminished, however, because the site was cored discontinuously, and no calcareous fossils were present to correlate the Radiolaria with foraminiferal or nannofossil assemblage zones. Preliminary dating of Radiolaria gives an average sedimentation rate of $23-45 \mathrm{~m} / \mathrm{m}$.y. for this site.

\section{Discussion}

Figure 6 summarizes the sedimentary sections sampled at Sites 250,251, and 252, together with the results of drilling at several nearby sites on Leg 25 (Schlich, Simpson, et al., in press).

Comparison of the results of drilling at Site 250 with those from Sites 248 and 249 sheds little light on the age of the separation of Africa and Antarctica. Site 249, which gives an Early Cretaceous (Neocomian) age for the basement, is situated on the Mozambique Ridge and it is unclear how this feature fits into the tectonic history of the region. Similarly, the applicability of the results of drilling at Site 248 is questionable. Basalt from this site gave a radiometric age of $72 \pm 7$ m.y. (SantonianMaestrichtian) (Schlich, Simpson, et al., in press), but it seems quite likely that drilling at this location sampled a sill rather than true basement. From the three sites no clear pattern of ages and age gradients emerges, nor do these ages fit the suggested tectonic history of the Mozambique Basin. However, the rifting of Africa from Antarctica can be no more recent than Early Cretaceous. This age would fit most tectonic hypotheses for the breakup of this portion of Gondwanaland. It should be pointed out that Upper Jurassic-Lower Cretaceous basalts are found along the southeastern margin of Africa (Flores, 1970). These basalts presumably reflect volcanic activity associated with the rifting of Gondwanaland, but not necessarily the dispersal of the continents and formation of the ocean floor (see discussion in Luyendyk, this volume, Chapter 37).

The age of the Southwest Branch as an active spreading center, was put at between 20 and 35 m.y. by McKenzie and Sclater (1971) based on a consideration of theoretical age/depth curves. As a result of drilling at Site 251 , we have been able to determine a spreading rate of $0.93 \mathrm{~cm} / \mathrm{yr}$, measured in a direction northnortheast, parallel to the fracture zones postulated in this region. This rate, when combined with geophysical observations between Sites 251 and 252 (see discussion in Luyendyk, this volume, Chapter 12) leads to the conclusion that the Southwest Branch can be no older than middle Eocene (ca 45 m.y.). The last episode of sea-floor spreading on the Carlsberg and Central Indian ridges began 36 m.y. ago (McKenzie and Sclater, 1971). Taking account of the uncertainties in the magnetic and bathymetric control, it is probable that active spreading on the Southwest Branch began at close to the same time as spreading on these other ridges.

At all the sites in the southwest Indian Ocean which sampled pre-Miocene sediment there is a significant gap in the record below the Miocene. At Sites 249 and 250 Miocene sediments overlie Cretaceous rocks, whereas at Sites 245, 246, and 248 they lie on Eocene sediments. The significance of this gap in the sedimentary record is discussed in a following section of this paper.

The evidence of seismic profiles, the observed high sedimentation rates, the major terrigenous component of the mid Miocene-Recent sediments, and the presence of shallow-water foraminifera in the sediments from Site 250 , are all compatible with the suggestion that sedimentation in the Mozambique Basin has been under the control of active bottom current circulation since sometime in the Miocene. As mentioned earlier, bottom water flows in a clockwise direction around the Mozambique Basin and sweeps with it shallow water and terrigenous debris from the southeast African continental margin, from the face of the Zambezi Fan, and from Madagascar. Southward-flowing water is diverted by the Southwest Branch from the eastern Mozambique Basin over the southern end of the Madagascar Ridge to mingle with water flowing north through fracture zones in the Southwest Branch into the Madagascar Basin. This current pattern represents a western boundary flow of cold Antarctic Bottom Water spreading north from the Weddell Sea (Heezen and Hollister, 1971). It probably did not come into existence before Antarctica had assumed its polar position and glaciation had commenced. It is presumably a consequence of this current system that sedimentation has been inhibited since the middle Miocene at Site 245 while south of the Southwest Branch, at Site 252, pelagic sedimentation has proceeded uninterrupted (Figure 6). The sediments at Site 248 are generally coarser than those at Site 250 , consisting mostly of silty clays, even some sand layers, with a major influx of terrigenous material in the mid Miocene. This reflects tectonic events on land in the early Tertiary which resulted in a flood of terrigenous material into the western Mozambique Basin in mid Miocene times (King, 1962). The coarse material accumulated in the western part of the basin (Site 248) but finer material was carried by bottom currents to accumulate at Site 250. The major influx of terrigenous material at Site 250, however, was in the Pliocene, reflecting the sudden increase in sediment transported by the Zambezi River as a result of vigorous erosion in response to Pliocene uplift and tilting of East Africa (King, 1962). Such an influx would not affect sedimentation at Site 248 since that site lies up current of the fan.

At Site 250 and at Site 248, carbonate-free clays are found overlying the basement basalt. This suggests that either these sites formed at unusually deep depths or that the carbonate compensation depth was very shallow in the Mozambique Basin during ConiacianPaleocene time. The latter seems more likely in view of the widely demonstrated relationship between age and depth of the ocean floor (Sclater et al., 1971) (see Figure 3 ). Site 251 , where pelagic carbonate sediments have accumulated throughout the record, shows distinct evidence of shoaling of the lysocline in the Miocene and deepening since then. 


\section{NINETYEAST RIDGE (SITES 253, 254)}

\section{Background}

The Ninetyeast Ridge is a linear crustal elevation approximately paralleling the $90^{\circ} \mathrm{E}$ meridian and extending northwards from $32^{\circ} \mathrm{S}$ to about $9^{\circ} \mathrm{N}$ where it becomes buried beneath the sediments of the Bengal Fan (Sclater and Fisher, 1974). The ridge has been traced in the subsurface to about $12^{\circ} \mathrm{N}$, using seismic reflection methods (Curray and Moore, 1971). The exposed part of the ridge rises 2000 meters above the adjacent sea floor and is about $100 \mathrm{~km}$ wide in places (Figure 7). Ninetyeast Ridge appears to have three distinct physiographic provinces: north of $7^{\circ} \mathrm{S}$, "en-echelon" symmetrical topography; between $7^{\circ} \mathrm{S}$ and Osborn Knoll $\left(14^{\circ}-16^{\circ} \mathrm{S}\right)$, narrow, linear, asymmetrical topography with steep east-facing slopes; and south of Osborn Knoll, where the ridge becomes wider and has more relief (see Sclater and Fisher, 1974, fig. 1). Sites 253 and 254 were drilled in the southern province.

Results of DSDP Leg 22 (Sclater et al., 1974) drilling north of Osborn Knoll (Sites 214, 216, 217) indicate that Ninetyeast Ridge has a shallow-water volcanic origin, and that it is approximately the same age as the Indian plate immediately to the west, which becomes older northwards (Sclater et al., 1974). East-west-trending magnetic anomalies are found to the east of the ridge in the Wharton Basin, but these become older southwards (Sclater and Fisher, 1974). This observation suggests that the Ninetyeast Ridge is an expression of a transform fault, or lies to the west of such a fault, but does not rule out the possibility that the ridge is also a nematath, or volcanic line generated from a point source. If the ridge were formed along a leaky transform, then because this transform healed when the Indian and Australian plates joined in the Oligocene, the ridge could be no younger than this.

\section{Drilling Results}

\section{Site 253}

This site is located in 1962 meters of water on the western flank of the Ninetyeast Ridge (Figure 7). The section here is divided into four units: two calcareous units, one of volcanic ash and lapilli and a basal basalt unit. The calcareous units are 9 meters of upper Pliocene to Recent foram-rich detrital clay and 144 meters of upper Eocene through upper Pliocene nannoplankton ooze and chalk. The volcanic unit is 388 meters of altered vitric volcanic ash and lapilli (middle Eocene) and consists of three lithic types: dark olive-green, greenish-gray micarb-bearing altered vitric volcanic ash; black altered vitric volcanic ash and minor lapilli (mollusc fragments are also present); and flows of black vesicular olivine basalt and scoria with carbonate fillings. Sedimentation of the ashes ceased about $42 \mathrm{~m}$.y. ago and the almost 400-meter-thick ash sequence appears to have been deposited in less than 4 m.y. The oldest datable sediment is middle Eocene, 5 meters above the basal basalt. Fossils in this volcanic unit include pelecypods bryozoans, crinoids, echinoids, solitary corals, and Discocyclina. This assemblage, plus benthonic

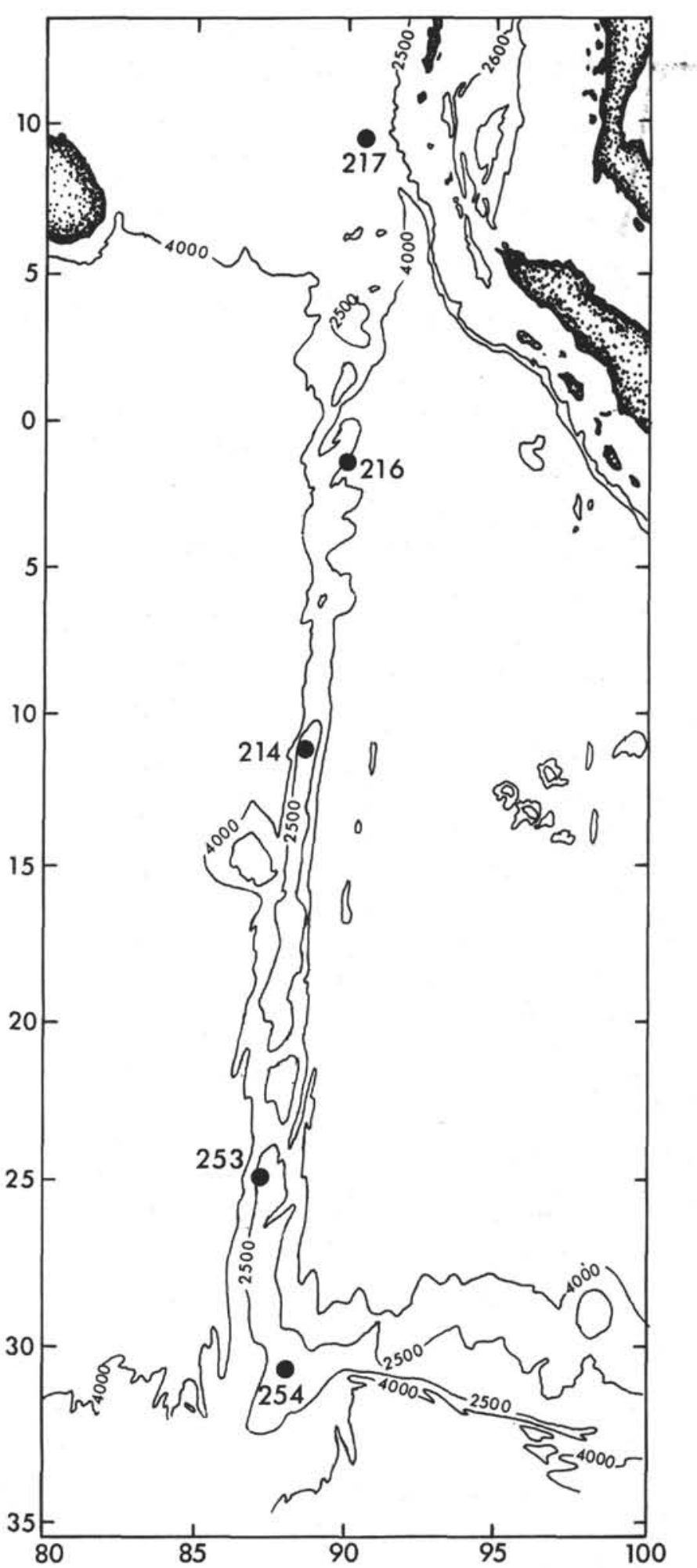

Figure 7. Locations of sites drilled on Ninetyeast Ridge (base map modified from Laughton et al., 1971).

foraminifera, represents an environment of the inner shelf (50-150 $\mathrm{m}$ of water). Three good down-hole temperature measurements at the site yield a heat flow of between 1.23 and $1.38 \mathrm{hfu}$. 


\section{Site 254}

Site 254 is located in 1253 meters of water on an isolated broad plateau atop the Ninetyeast Ridge (Figure 7). The location is just south of the apparent intersection of Broken Ridge with Ninetyeast Ridge. The sedimentary section can be divided into four lithologic units overlying a basalt flow sequence. The upper three of these form a sequence of biogenous oozes, and the fourth is a sequence of volcanic silty sandstones and mudstones. Thin-walled macrofossil debris is common in the top part of the volcanic unit but absent in the lower 300 meters. The volcanic sediments contain a distinctly littoral assemblage of foraminifera with some shallow-water ostracod species and well-preserved but fragile pelecypods and small gastropods. The paleontologic data from this site are confusing. Near the base of the calcareous section benthonic foraminifera were found which are restricted to the middle and late Eocene. On the other hand, ostracods in the volcanic sediments point to an Eocene or Oligocene age, and molluscs indicate Oligocene or Miocene. Furthermore, pollen analysis of this unit gives a Miocene or younger age (Kemp, this volume, Chapter 34). Radiometric age determinations on basalts from this site give an age of middle Eocene or younger (Rundle et al., this volume, Chapter 17). We will tentatively conclude that the age is early Oligocene-late Eocene. The contact between the sediments and the basement olivine basalts is depositional, weathered basalt being overlain by ferruginous silty clays and fine sandstones containing weathered fragments of the underlying basalt. Downhole temperature measurements at the site give a heat flow of $1.25 \pm 0.15 \mathrm{hfu}$.

\section{Discussion}

\section{Stratigraphy and Geology of the Ninetyeast Ridge}

The drilling results for Leg 26 are compared with the Leg 22 results from the Ninetyeast Ridge (Sites 214, 216, 217 , von der Borch, Sclater, et al., 1974) in Figure 8. Several general observations can be made.

First, the sites become progressively older to the north, which matches the direction of the age gradient in the Central Indian Basin and opposes the gradient in the Wharton Basin to the east. Further, where the ages can be well defined, they match ages on the Indian plate immediately to the west predicted by magnetic anomaly matching and drilling results (Sclater and Fisher, 1974; Sclater et al., 1974; and Leg 26 results). This leads to the conclusion that the ridge belongs, tectonically, to the Indian plate.

Second, the stratigraphic sections consist of a largely pelagic calcareous sequence above a sequence of pyroclastics or detrital volcanic sediments.

Third, the basal volcanic units have been deposited in shallow or littoral conditions indicating that the Ninetyeast Ridge formed near sea level. It then subsided with time at a rate comparable to that for normal oceanic lithosphere. The general increase in crestal depth northward along the ridge agrees with the empirical age-depth curves for ocean basins (with an appropriate offset; Sclater and Fisher, 1974; Bowin, 1973).
Fourth, two hiatuses can be recognized in the calcareous section. One is centered on the early Eocene and the other on the late Eocene-early Oligocene (Pimm, 1974; discussion below). At Site 253 a small section of the upper Eocene is missing. At Site 254 the stratigraphic control is too uncertain to determine whether any of the Oligocene is missing. We have plotted the lithologies of the Ninetyeast Ridge sites on paleodepth curves in Figure 9. These data show that whatever the cause of the Oligocene hiatus, it operated over a depth range from less than 1000 meters to about 2700 meters. Figure 9 also shows that Site 253 formed at or slightly above sea level; also, the top of the ash sequence here "backtracks" to sea level at 42 m.y.B.P. At $42 \mathrm{~m} . \mathrm{y} . \mathrm{B}$.P. the difference in these two curves is 400 meters, close to the measured thickness of the ash sequence, showing that the net sedimentation of the ash kept pace with basement subsidence for the period $46-42$ m.y.B.P. Assuming an age of $38 \mathrm{~m}$.y. for Site 254, this site would then have formed above sea level and would have sunk below sea level at $31 \mathrm{~m} . \mathrm{y}$., which would explain the confused pre-upper Oligocene stratigraphy and the littoral faunas found deeper in the section.

Finally, paleontologic data from all sites show progressively warmer water species with decreasing age (Sclater et al., 1974; this volume, Chapters 6 and 7) indicating that the sites have been formed in more southerly latitudes and since have moved north. This, of course, supports the idea that the ridge is attached to the Indian plate since it is well known that India has moved a considerable distance north during the Mesozoic and Cenozoic (e.g., McElhinney, 1970; Sclater and Fisher, 1974). Studies on the paleomagnetism of Site 253 and 254 basalts (Pierce et al., this volume, Chapter 18) again support the interpretation that this section of the ridge formed in more southerly latitudes.

\section{Tectonic History of the Ninetyeast Ridge}

Tectonic models of the ridge must account for the following facts:

1) The Ninetyeast Ridge has a shallow-water volcanic origin and ranges in age from Late Cretaceous to Oligocene (Eocene).

2) Most or all of it belongs tectonically to the Indian plate. In the north it is the same age as the plate, but in the south it may be younger.

3) Because parts of it are generally the same age as the Indian plate immediately to the west, it must have been formed very close to the crest of the ancient Southeast Branch.

4) The fact that the Ninetyeast Ridge shows NNESSW "en-echelon" topography north of about $7^{\circ} \mathrm{S}$ (equivalent age 60 m.y.; Sclater and Fisher, 1974) and pronounced asymmetry with sharp eastern slopes south of here, being narrow from $7^{\circ} \mathrm{S}$ to Osborn Knoll and wider south of the knoll, suggests the possibility of different origins for different portions of the ridge.

Several possible models for the Ninetyeast Ridge can be discounted as a result of recent work. It has been shown, from gravity studies, that the ridge cannot be a horst (Bowin, 1973). The drilling results also rule out the possibility of uplift, as suggested by McKenzie and Sclater (1971). 
SITE 254

$30^{\circ} 58^{\circ} \mathrm{S} \quad 87^{\circ} 54^{\prime} \mathrm{E}$

1253 "

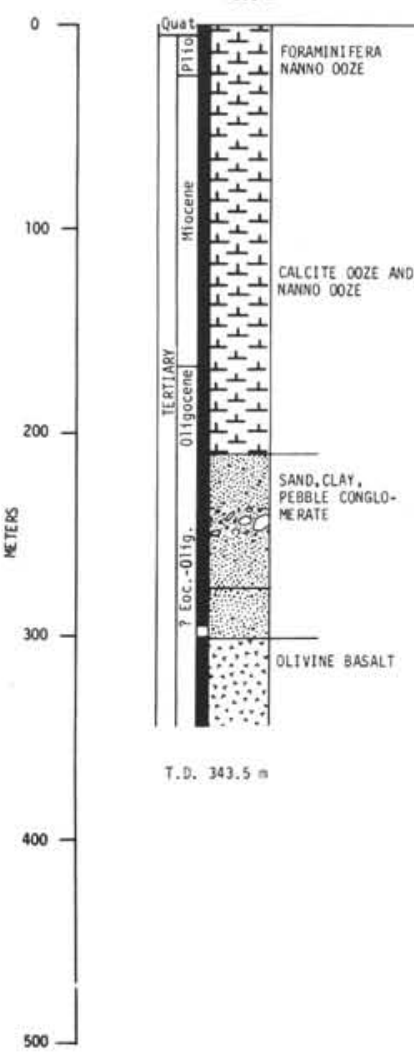

SITE 253

$4^{\circ} 53^{\prime \prime} 587^{\circ} 22^{\prime} E$

$1962 \mathrm{~m}$

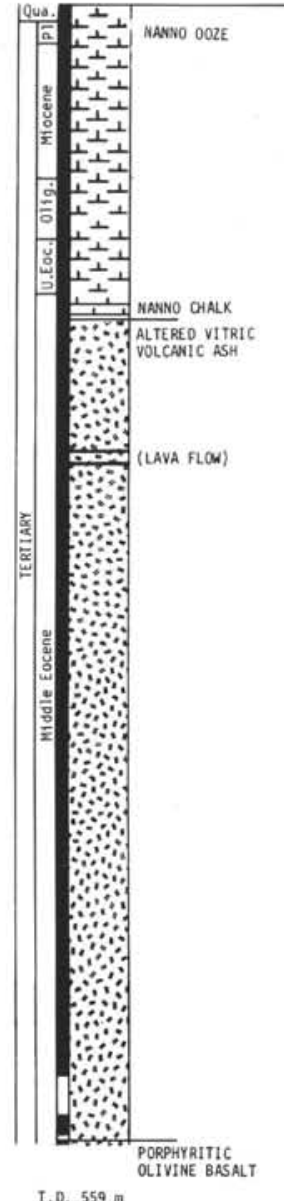

SITE $\cdot 214$

$110.002588^{\circ}$
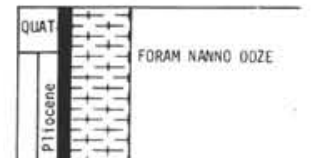

SITE 216

$01^{\circ} 28^{\prime} \times 90^{\circ} 12^{\prime}$

$2247 \mathrm{~m}$

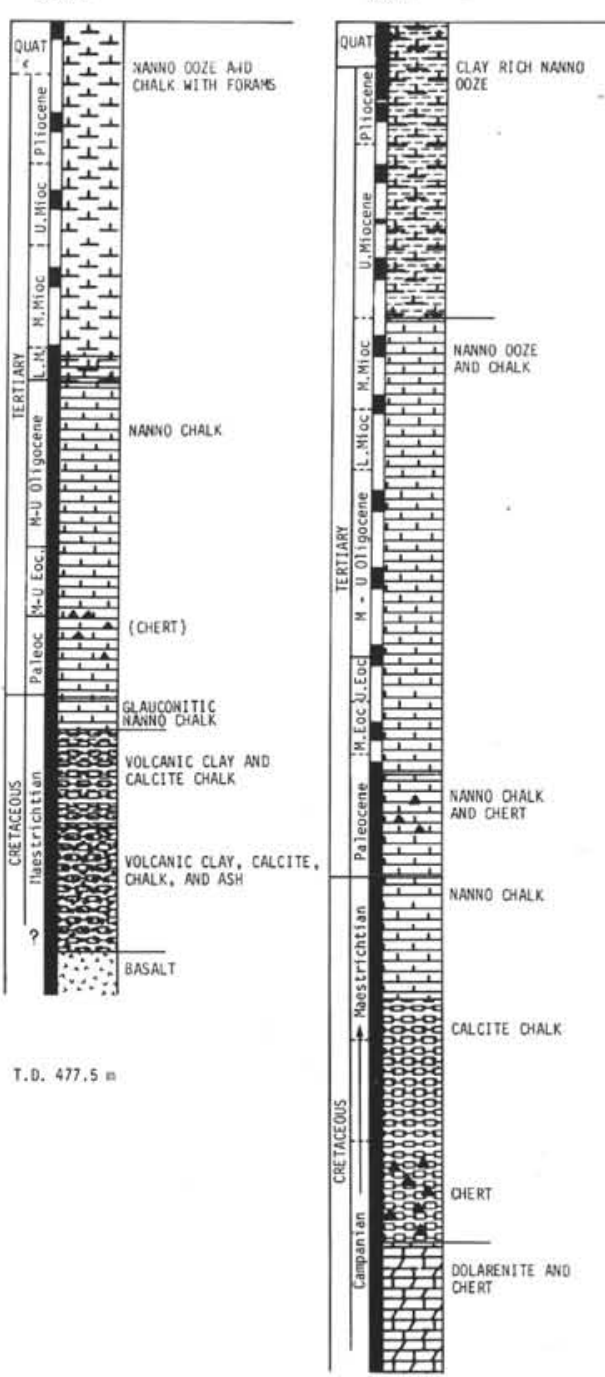

T. D. 614,5

SITE 217

$08^{\circ} 56^{\circ} \mathrm{N} 90^{\circ} 32^{\circ}$

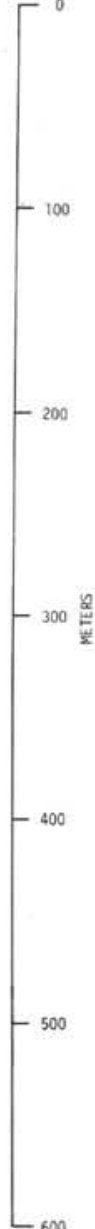

Figure 8. Stratigraphy of sites drilled on the Ninetyeast Ridge (see Figure 7 for locations). Data from von der Borch, Sclater, et al., 1974; and Leg 26. 


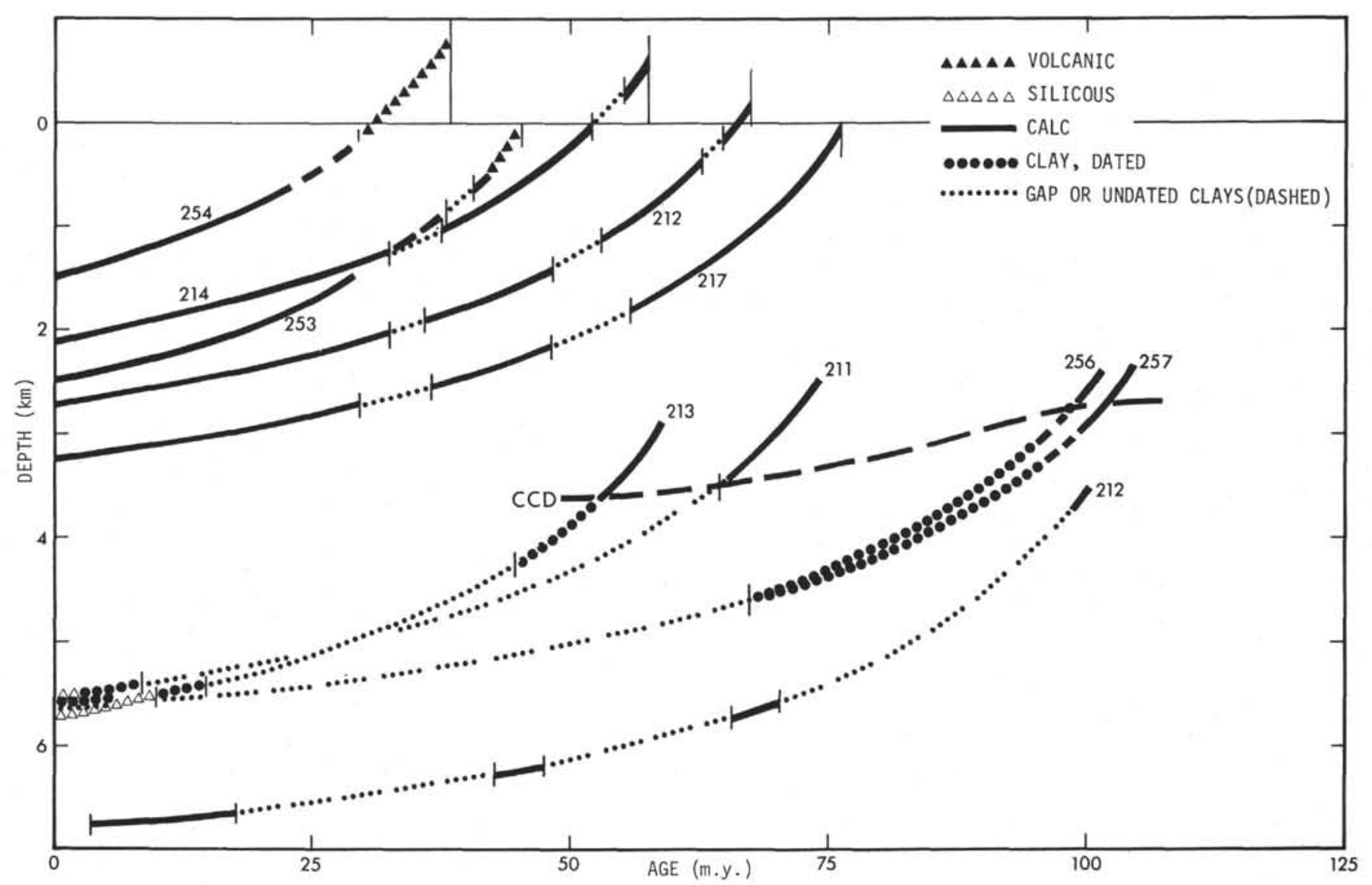

Figure 9. Paleodepth and lithology of sites drilled on Ninetyeast Ridge and in the Wharton Basin.

Sclater and Fisher (1974) have deduced a tectonic model for the eastern Indian Ocean which puts constraints on ideas concerning the evolution of the ridge. Briefly, their model calls for the origin of the Ninetyeast Ridge to be related to transform faulting between the Indian and Antarctic (including Australia) plates from the Mid-Cretaceous to early Eocene, and a transform between the Indian and Australian plates from the early Eocene until the early Oligocene when these two plates joined and became one, leaving the ridge as an aseismic feature. This model would also allow the possibility of renewed movement along the northern portions of the ridge in the post-early Eocene when a fourth plate supposedly broke off the Australian plate (Figure 10). This renewed relative motion was left-lateral (op. cit.) and thus cannot be the cause of the observed en-echelon topography. This topography might be right-lateral "drag folding" formed along the transform segment of the ridge during the early Tertiary.

It should be stressed that the possible role of the Ninetyeast Ridge as a transform fault does not explain (a) its elevation and therefore its structural origin, and (b) why it is restricted to the Indian plate and not shared with the Australian plate. Regarding this last point, Sclater and Fisher (1974) have noted deep linear troughs on the east of the Ridge. Evidently these are the old fracture zones marking the boundary between the Indian and Australian-Antarctic plates. Sclater and
Fisher (1974) have proposed that the ridge is the trace of a volcanic point source on the Indian plate, combined in some way with a leaky transform fault. This idea follows the suggestion of Morgan (1972), among others, and implies that the ridge has an origin similar to the Walvis Ridge and Rio Grande Rise in the South Atlantic. If the ridge is a plume trace, then it does seem a coincidence that it parallels a transform fault.

In such models employing point volcanic sources, the relative motions of the source, the Indian plate, Antarctic-Australian plate, and the ancient Southeast Branch ridge crest, become critical. Since the Ninetyeast Ridge has a shallow-water origin and is the same age as the Indian plate, then an important corollary follows: namely, the volcanic source and the ridge crest must have been fixed relative to one another. If the source was fixed exactly at the crest, then symmetrical ridges would be generated about the spreading center, as in the south Atlantic (Figure 11). If the source were fixed relative to the crest, but displaced slightly to the north under the Indian plate, then the ridge would be generated only on the Indian plate and would be slightly younger than the crust to the west (age difference depending on offset and spreading rate; Figure 11). Either way the source must be fixed relative to the crest to account for this simple geology. Because the Indian plate has drifted north while the Antarctic plate has remained fairly fixed relative to the north pole (McElhinney, 

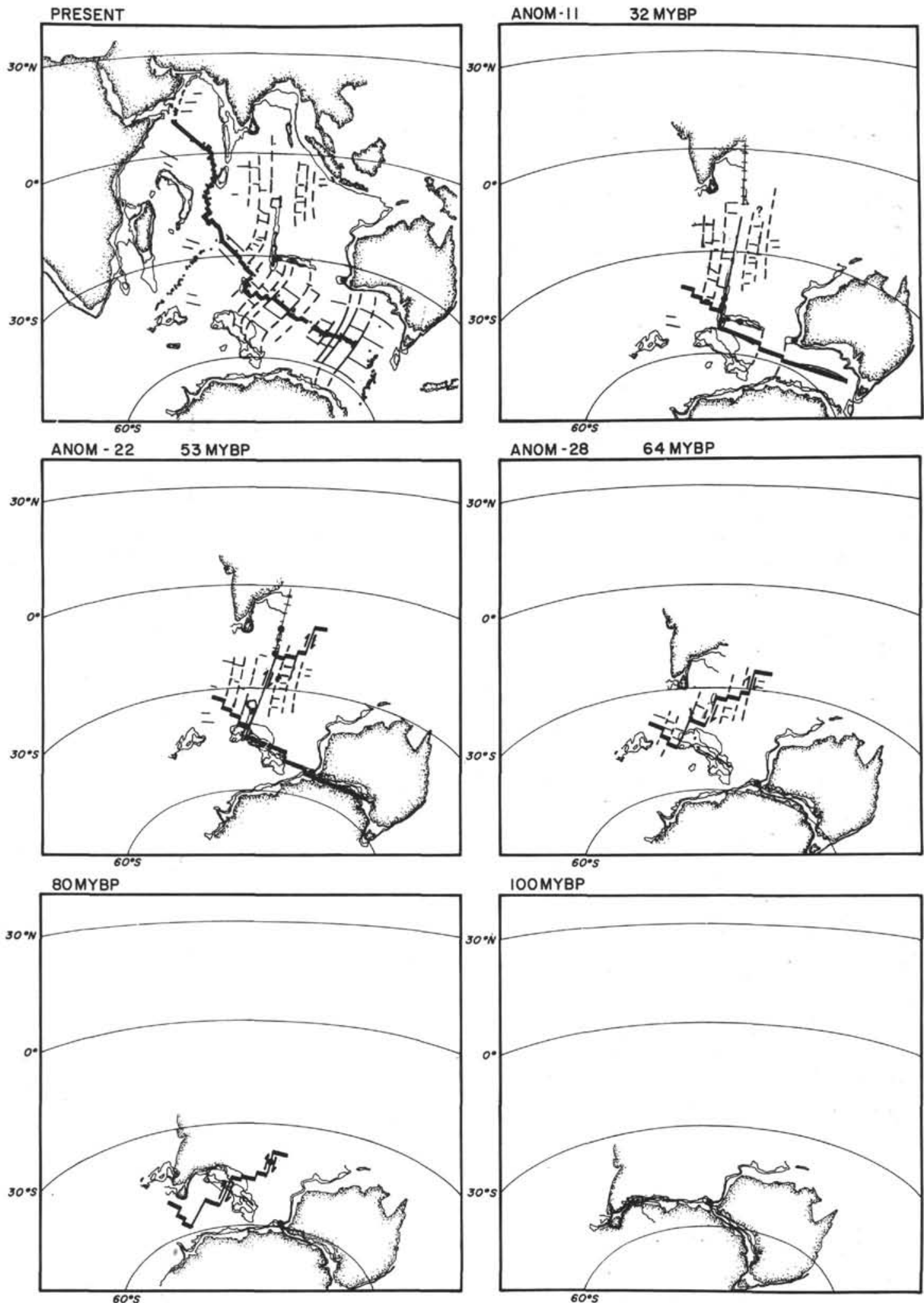

Figure 10. Reconstruction of the relative positions of India, Australia, and Antarctica since the breakup of this part of Gondwanaland. From Sclater et al., 1974. 

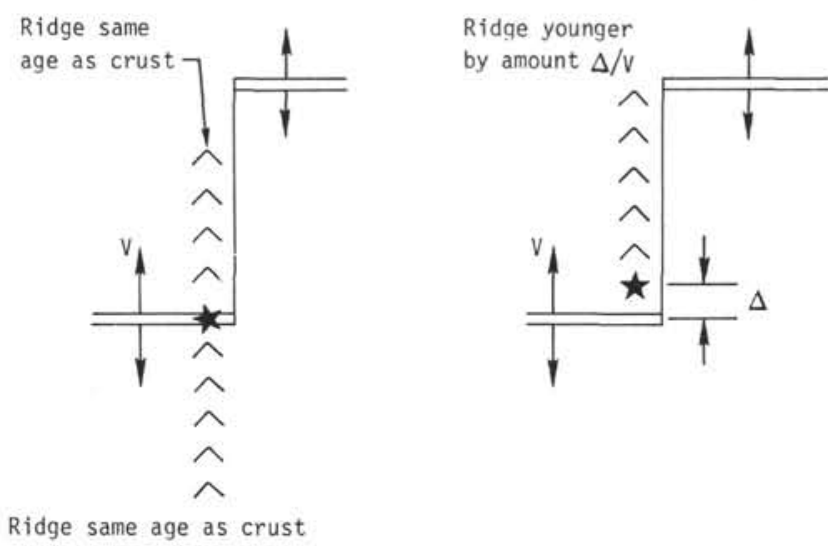

Figure 11. Models for formation of an aseismic ridge from a volcanic plume with the plume fixed at the ridge crest (left) and fixed relative to the crest but offset north (right). Velocity arrows are relative to the spot.

1970), the ridge crest of the Southeast Branch and the volcanic source must have drifted north at half the rate of India. Thus, a fixed mantle plume in the sense of Morgan (1972) does not fit this present discussion unless we allow the Indian and Antarctic plates a complicated pattern of motion relative to any volcanic source, and the ridge to have a more complicated geology than is presently assumed.

The fact that the active Amsterdam-St. Paul volcanic complex connects to the end of the Ninetyeast Ridge after Oligocene spreading on the Southeast Branch is removed compels us to seek explanations relating the origin of the ridge to a point volcanic source where all plates (and ridges), and the source are in relative motion. We will follow the constraints of Sclater and Fisher's reconstructions (Figure 10) for plate motions relative to the paleomagnetic poles and assume, for a first approximation, that the volcanic source is fixed in this reference frame. Our model calls for three different origins for the ridge. Above $7^{\circ} \mathrm{S}$ the ridge is a true trace of a volcanic point source. Here it is about the same age as the plate on which it rests. Between $7^{\circ} \mathrm{S}$ and Osborn $\mathrm{Knoll}$ it formed by leaking along the transform boundary and is thus younger than the Indian plate. Below Osborn Knoll, the ridge was formed as a volcanic trace on the Antarctic plate and was later overprinted by volcanism along a transform formed by the southward jump of the Southeast Branch. At its southernmost tip the ridge is again a volcanic trail. This multifaceted origin fits the observation of en-echelon and symmetric topography north of $7^{\circ} \mathrm{S}$, linear topography with lower relief between here and Osborn Knoll to the south, and linear topography with more relief and width south of the knoll. We still cannot explain the sharp eastern slopes in the southern regions of the ridge, or why the feature is apparently restricted to the ancient Indian plate.

Figure 12 shows a simplified version of the proposed sequence of events.

1) $110-80 \mathrm{~m} . y$. The India-Australia-Antarctic rift has formed over the volcanic source. Incipient rifting

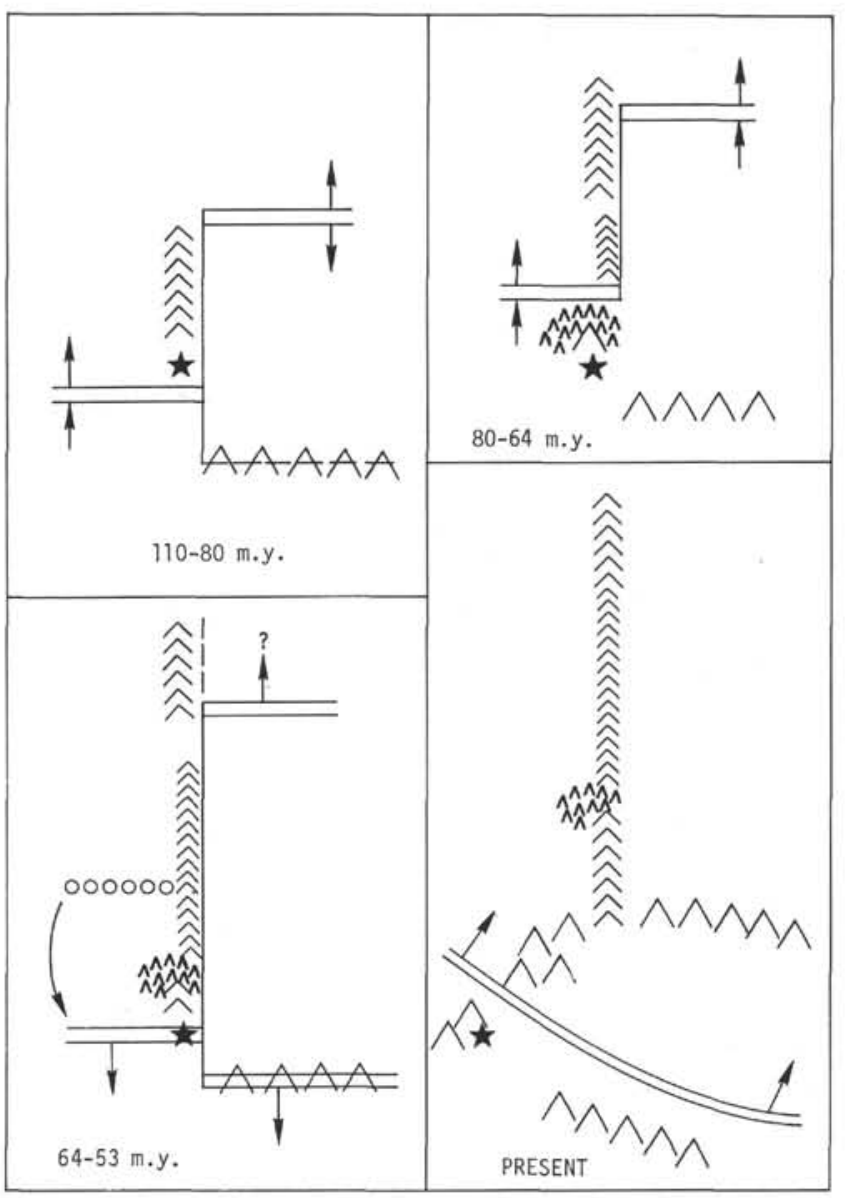

Figure 12. Hypothetical step-wise evolution scheme for the Ninetyeast Ridge. (Explained in detail in text).

between Australia and Antarctica (Luyendyk, this volume, Chapter 37; Brown et al., 1968) has caused a volcanic upwelling from this source to form Naturaliste Plateau, Broken Ridge-Kerguelen Plateau, and to start the Ninetyeast Ridge. For the time period 110-80 m.y. the Southeast Branch crest was fixed relative to the poles, and thus fixed relative to the volcanic source under our assumptions. Assuming the source to be displaced slightly north of the crest, under the Indian plate, the Ninetyeast Ridge is generated only on this plate and has approximately the same age.

2) 80-64 m.y. The crest of the Southeast Branch has moved north relative to the magnetic poles and the volcanic source. As the ridge crosses north of the source, the Indian plate is cut off from its volcanic supply to construct the ridge. Because the Antarctic plate at first moves very slowly north, Osborn Knoll accumulates from the source as a volcanic pile on this plate. The youngest section of Ninetyeast Ridge formed from the spot is about $60 \mathrm{~m} . y$. old and marks the southern limit of the "en-echelon" topography presently at $7^{\circ} \mathrm{S}$. The remainder of the Ninetyeast Ridge is then filled in below this point by leaking along the India-Antarctic transform system. Therefore, this latter section of the ridge should be younger than the crust to the west, and its source may not necessarily be the "hot spot." 
3) 64-53 m.y. During this time the ridge crest and Antarctic plate are moving north from the spot, causing the Ninetyeast Ridge to be built on the Antarctic plate and to be younger than crust on which it rests. This continues until about 50 m.y. B.P. at which time the ridge crest jumps south to relocate over the spot and extend the Indian-Antarctic transform (Sclater and Fisher, 1974). Also, Antarctica has begun to rift south away from Australia taking Kerguelen Plateau with it and forming the Australian plate. Extension of the transform promotes further leaking which overprints the ridge south of Osborn Knoll with younger rocks.

4) 53-32 m.y. During this time the Indian plate remains remarkably fixed relative to the poles and near the equator. Using our assumptions then, the Southeast Branch moves south away from the volcanic source, and the Ninetyeast Ridge continues to be built from a leaky transform opening between the Indian and Australian plates.

5) 32-0 m.y. Somewhere around 30 m.y. several events occur. The Indian and Australia plates weld together at the Ninetyeast Ridge transform, and IndiaAustralia begin to move northeast with Antarctica fixed relative to the poles. This causes the Southeast Branch to move north, and the southern end of the Ninetyeast Ridge is generated as a trail from the volcanic source until the ridge crosses it. The source is now isolated under the Antarctic plate and fixed relative to it and is constructing the islands of Amsterdam-St. Paul.

\section{BROKEN RIDGE-NATURALISTE PLATEAU (SITES 255, 258)}

\section{Background}

Broken Ridge is one of the enigmatic shallow submarine features of the Indian Ocean. It extends eastwards from near the southern end of Ninetyeast Ridge for about $1000 \mathrm{~km}$ and is about $500 \mathrm{~km}$ wide. It is not known whether Broken Ridge and Ninetyeast Ridge are joined structurally and topographically, or whether they are quite unrelated features. The bathymetry of Broken Ridge is shown in Figure 13. The southern boundary of the ridge is a steep, south-facing scarp falling about $4 \mathrm{~km}$ into the $\mathrm{Ob}$ Trench. The crest of the ridge is within $1 \mathrm{~km}$ of sea level at some points and generally lies between 1 and $1.5 \mathrm{~km}$ deep. In contrast to the steep southern scarp, the ridge slopes gently northwards to the abyssal depths of the south Wharton Basin, some $500 \mathrm{~km}$ to the north.

Naturaliste Plateau is a submerged western extension of the southwest Australian continental margin (Figure 13). Summit depths on the plateau are near 2500 meters. Its southern edge is steep and trends east-west, parallel to the southern Australian margin and the Diamantina Fracture Zone. The northern slope of the plateau is, by contrast, rather gentle.

The Naturaliste Plateau and Broken Ridge seem to lie on a single structural trend parallel to the Diamantina Fracture Zone and $\mathrm{Ob}$ Trench, although they are separated from one another by a deep-sea gap about 600 $\mathrm{km}$ wide. Because of this there has been speculation that both Broken Ridge and Naturaliste Plateau may be con- tinental structures, although rock samples are lacking to confirm or deny this. The strongest evidence in support of a continental origin for Broken Ridge is the seismic refraction work of Francis and Raitt (1967) which shows a continental-type velocity structure and a crustal thickness of some $18 \mathrm{~km}$. Kerguelen Plateau is a structure analogous to Broken Ridge which is located south of the Southeast Branch of the Indian Ocean Ridge. This geometry has lead to suggestions that Kerguelen Plateau and Broken Ridge are two parts of an original structure which separated in the Eocene when Australia and Antarctica rifted apart. Kerguelen Island does have late Tertiary alkali syenite intrusions, but these are latestage differentiates similar to those found on other oceanic islands (Watkins et al., 1974). Watkins et al. conclude that there is no evidence for a continental origin for the Kerguelen Plateau and suggest that such an origin is unlikely. Drilling at Site 255 has shown that Broken Ridge existed as a shallow-marine structure at least 80 m.y. ago (basement was not sampled). Similarly, drilling results from the Naturaliste Plateau show it to have been a marine feature since at least the middle Albian, say 105 m.y. ago.

\section{Drilling Results}

\section{Site 255 (Broken Ridge)}

Site 255 is located atop Broken Ridge near its southern edge (Figure 13). Near the site seismic profiles show a $0.1 \mathrm{sec}$ DT or thinner transparent layer unconformably overlying a north-dipping reflective sequence (Figure 14). The angular unconformity is subhorizontal and gives a very strong reflection. At about $0.3 \mathrm{sec}$ DT acoustic basement is seen below the intermediate unit, also dipping north. The oldest sediment was recovered from 108.5 meters subbottom and is biomicritic limestone of Santonian age. The sediments sampled at this site are divided into three units (Figure 15). An upper Miocene to Recent sequence of unconsolidated carbonate ooze overlies an Eocene coarse gravel containing mollusc and chert fragments and bryozoans. The lower part of the gravelly unit is a yellow calcareous chalk. There may be a disconformity between the upper ooze and the gravel. A major angular unconformity separates the Eocene gravel and chalk from the Santonian basal limestone which dips at $15^{\circ}$ to $30^{\circ}$. Molluscs are seen along some bedding planes in the limestone. The mixed faunal assemblage of the upper ooze sequence indicates transport and resedimentation. Reworked Oligocene forms are found at the base of the unit. The underlying gravels contain Eocene floras and faunas at the base. The faunas suggest a shallow littoral environment in the Eocene followed by open-sea conditions in the Oligocene. The basal limestone contains planktonic and benthonic forms indicating deposition in the shallow, quiet waters of the outer shelf environment, with water depths no more than a few hundred meters. The fauna also suggests a cold-water environment during the Santonian. No reworked Paleocene fauna were found in the entire section. Because of low core recovery, sedimentation rates are hard to determine; they can be estimated as $2.4 \mathrm{~m} / \mathrm{m}$.y. for the Tertiary ooze and a minimum of $6.7 \mathrm{~m} / \mathrm{m} . \mathrm{y}$. for the Cretaceous limestone. 


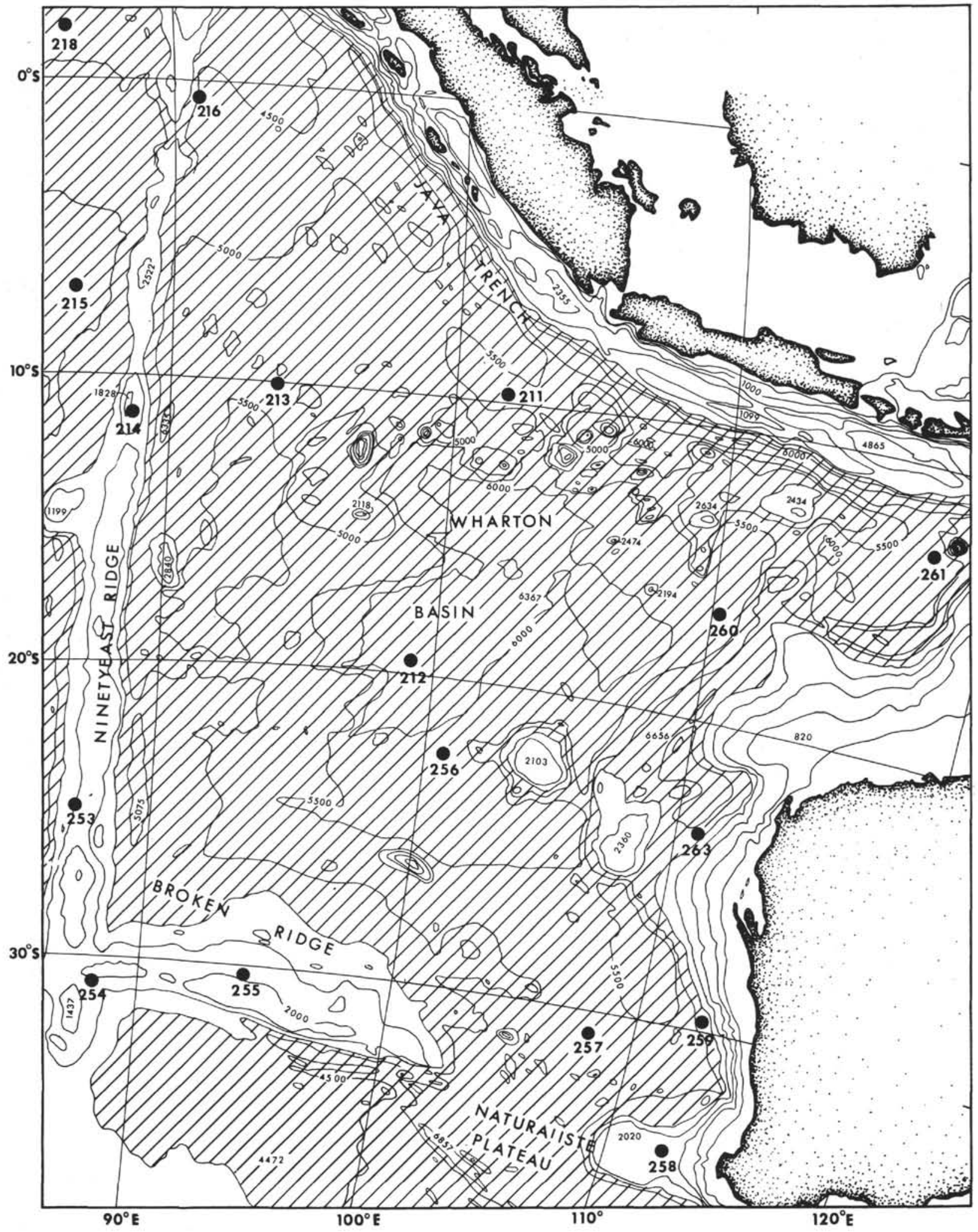

Figure 13. Bathymetry of the eastern Indian Ocean (southern Wharton Basin) showing Deep Sea Drilling Project sites. 


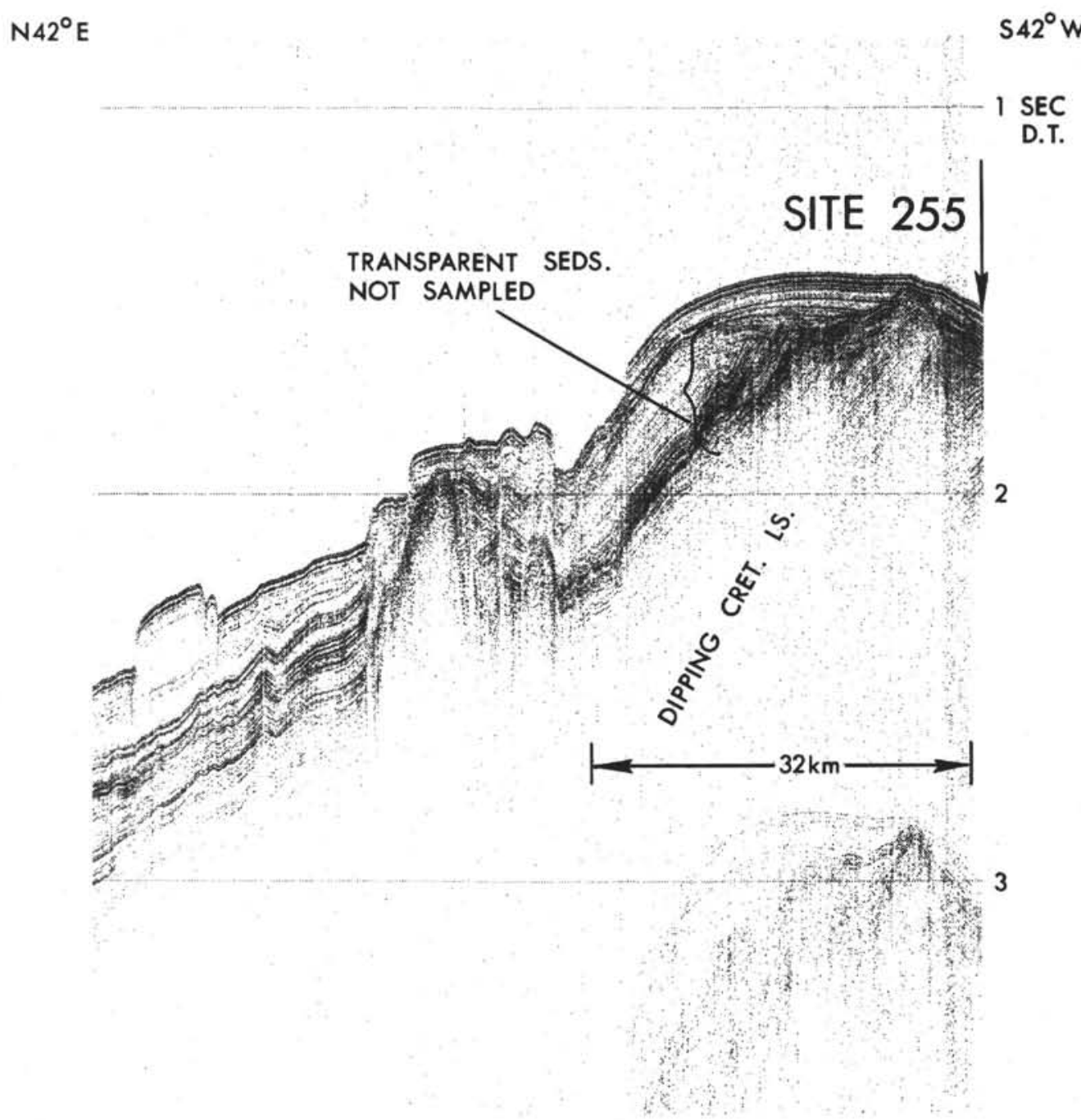

Figure 14. Seismic profile of Broken Ridge.

\section{Site 258 (Naturaliste Plateau)}

Site 258 is located on the northern slope of the Naturaliste Plateau (Figure 13). Two holes were drilled. The first (Hole 258) penetrated 525 meters before rough weather forced us to suspend operations for about 15 hours. Hole 258A was drilled to 123.5 meters in order to fill in some gaps in the previous sampling of the upper parts of the section. The oldest precisely datable sediment reached was middle Albian, found at 444 meters in Hole 258. Five lithologic units can be recognized (Figure $15)$. From the surface down to 114 meters is a sequence of white and gray soft oozes ranging from late Miocene to Recent in age. Towards the bottom of this unit, especially in the Miocene, planktonic and shallow-water (slope facies) benthonic foraminifera appear. Reworked littoral forms are also found. Beneath this is silicified limestone and chalk overlying micarb (recrystallized) chalk, which ranges from Cenomanian to Santonian in age. The boundary between the Santonian and Miocene sediments is sharp and well defined. A transitional unit separates the chalk from the underlying dark ferruginous clays. These clays are almost black and contain many diagenetic minerals (alkali feldspar, siderite, zeolites, etc.) and are of middle and late Albian age. At the bottom of the hole is a Lower Cretaceous (undefined range) sequence of glauconitic sand and muddy silt, well sorted, and in many cases showing graded bedding. The sediments become coarser downwards. There is common, but as yet indeterminate, macrofossil debris and many deep-water benthonic foraminifera. The planktonic foraminifera are represented by only one species. Much of the Albian and older sediment was apparently derived from the erosion of basaltic volcanic rocks. Sedimentation rates were high in the Lower Cretaceous (at least $45 \mathrm{~m} / \mathrm{m} . \mathrm{y}$.) and in the Upper Cretaceous $(12.6 \mathrm{~m} / \mathrm{m} . \mathrm{y}$.$) and Tertiary (14-17 \mathrm{~m} / \mathrm{m} . \mathrm{y}$. but clearly very much lower in the Cenomanian and Turonian $(1.8 \mathrm{~m} / \mathrm{m} . \mathrm{y}$.). The unconformity between the Santonian and the Miocene represents a gap in the sedimentary record of at least 66 m.y. 


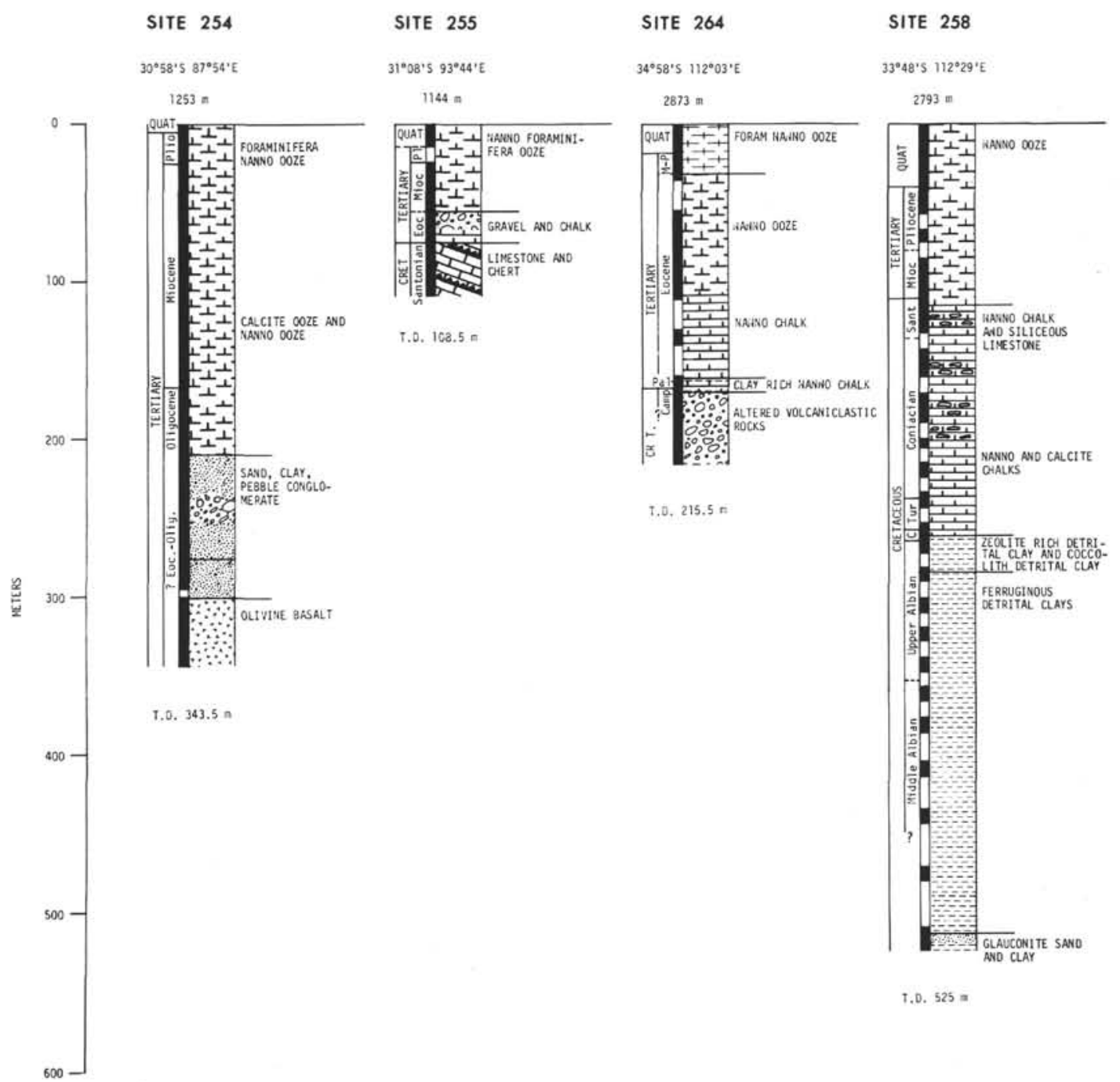

Figure 15. Stratigraphy of sites drilled at the south end of Ninetyeast Ridge, on Broken Ridge, and on Naturaliste Plateau (see Figure 12 for locations). Data from Hayes, Frakes, et al., 1973; and Leg 26.

\section{Discussion}

The results of drilling at Sites 255 and 258, together with the most southerly site on Ninetyeast Ridge, Site 254 situated near the join with Broken Ridge, and Site 264, a second site drilled on Naturaliste Plateau by Leg 28 (Hayes et al., 1973), are summarized in Figure 15.

As was mentioned earlier, the question of the continental versus oceanic affinities of Broken Ridge and the Naturaliste Plateau remains unresolved. It is quite clear, however, that these areas existed as shallow seas (?ridges or platforms) prior to the separation of Australia and Antarctica, and that Broken Ridge is much older than the adjacent southern end of Ninetyeast Ridge. In the previous section of this paper reference was made to the possible origin of these features as the result of volcanic activity during the Early Cretaceous along the zone of incipient rifting between Australia and Antarctica. This suggestion is further strengthened by the occurrence of Albian detrital volcanic sediments at Site 258 and Campanian and older coarse detrital volcanic rocks at Site 264 (Hayes et al., 1973). Basalts of Early Cretaceous age also occur in the Perth Basin (Brown et al., 1968). Drilling on Broken Ridge did not penetrate beyond the Santonian, but it seems likely that it is the same age and of similar origin to the Naturaliste Plateau.

During the later part of the Cretaceous, both Broken Ridge and Naturaliste Plateau seem to have been areas of quiet pelagic sedimentation. Foraminiferal evidence suggests a gradual shoaling of the Naturaliste Plateau (or deepening of the lysocline) through this time. For Broken Ridge there is no clear evidence of vertical movements; however, from the seismic profile (Figure 14) it is apparent that the Cretaceous limestone is at least $1.3 \mathrm{~km}$ thick which would suggest that the region of the ridge must have been above the lysocline and steadily subsiding through the later Cretaceous and Paleocene.

Sometime between the Late Cretaceous and late Eocene there must have been significant uplift and 
tilting of Broken Ridge. The Cretaceous limestones are clearly dipping and have been truncated by erosion (Figure 14). It seems reasonable to assume that this uplift was general along the line of rifting between Australia and Antarctica associated with the initiation of spreading along the Southeast Branch and the Pacific-Antarctic Ridge in the early Eocene ( 55 m.y.B.P. according to Weissel and Hayes, 1971). Such uplift would clearly have affected the Naturaliste Plateau also. If we assume that Broken Ridge has subsided to its present depth since the initiation of spreading on the Southeast Branch and use the age/depth curve (Figure 3) to determine paleobathymetry, it is apparent that Broken Ridge was above sea level prior to about 38 m.y. ago (Figure 16). It is perhaps not surprising then that the oldest sediments found on the truncated surface of the Cretaceous limestone at Site 255 are upper Eocene beach gravels. A similar "back-track" for the Naturaliste Plateau suggests that it rose close to sea level but not above, although it is questionable whether the simple age/depth curve is applicable to a location so close to a continental landmass. At Site 258 the entire sequence between the Santonian and upper Miocene is absent, but at Site 264 a thin mid-Paleocene section overlies Campanian sediments and is overlain in turn by a thicker upper lower and middle Eocene sequence. This suggests that there was sufficient bottom current activity in the Late Cretaceous-early Tertiary to inhibit sedimentation, except for a short period in the mid Paleocene.

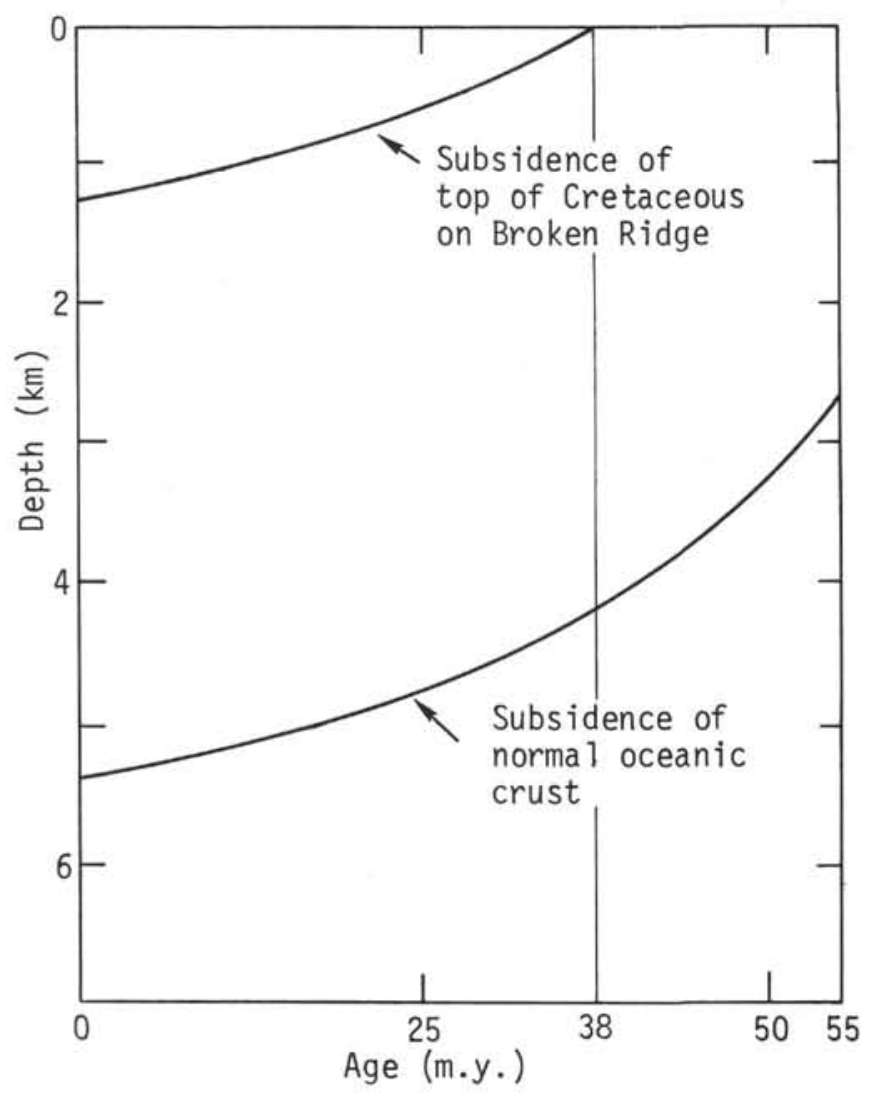

Figure 16. Paleodepth curve for the top of the Cretaceous limestone at Site 255.
This intensification of current activity could be a result of the uplift of the region associated with the separation of Australia and Antarctica.

The upper Miocene-Santonian gap in the sedimentary record at Site 258 and the upper Miocene-upper Eocene gap in the record at Site 264 are likely the result of initiation of strong circumpolar circulation in the Oligocene (Kennett et al., 1972). The Eocene and Paleocene sediments preserved at Site 264 probably represent relict deposits since the site is located in a topographic depression. The subject of unconformities is further discussed in a later section of the paper.

The Eocene-Miocene part of the section on Broken Ridge is either extremely thin or missing, recoveries were too poor for us to be certain. Reworked Oligocene fossils are found in the basal Miocene sediments.

Since the Miocene, both Broken Ridge and Naturaliste Plateau have been receiving pelagic carbonate sediments; both sites are above the lysocline. There is foraminiferal evidence for Naturaliste Plateau being significantly shallower than its present depth during the very early Pliocene.

\section{WHARTON BASIN (SITES 256, 257)}

\section{Background}

Some reconstructions of Gondwanaland show a marine gap between India, Australia, and Antarctica (e.g., DuToit, 1937). The predrift sea floor in the gap hypothesized by these models could be quite old, as suggested by Dietz and Holden (1971) and could be in the Wharton Basin. The great water depths in the Wharton Basin led McKenzie and Sclater (1971) to suggest that this basin was Cretaceous or older. Leg 22 of DSDP found that in the north at least the basin was Late Cretaceous. Also, Sclater and Fisher (1974) found Cenozoic marine magnetic anomalies trending east-west in this part of the basin which became older southwards. These observations donot rule out the possibility of finding pre-Mesozoic crust in the southern Wharton Basin, but they make this hypothesis less likely.

It has also been suggested that the east coast of India was up against west Australia in Gondwanaland (Veevers et al., 1971; Crawford, 1969) rather than against east Antarctica (e.g., DuToit, 1937). If this is so, then east-west spreading separated India from Australia. This idea may or may not conflict with the observation of north-south spreading in the northern Wharton Basin by Sclater and Fisher. Unfortunately, lineated magnetic anomalies cannot be recognized in the Southern Basin to test this idea. In the case of either spreading direction the oldest sea floor should be up against Australia, or off southwest Australia for north-south spreading. Site 257 was drilled in an attempt to find the oldest sea floor. The combination of ages at Sites 256 and 257 could establish the age gradient and direction of spreading. If the spreading were north-south, Site 257 would be older than Sites 256 and 212 ( Leg 22) in some reasonable proportion. If the spreading were east-west, then the age difference between Sites 257 and 256 would be much greater than that between Sites 256 and 212 (see Figure 13). 


\section{Drilling Results}

\section{Site 256}

This site is located in 5361 meters of water in an area of abyssal hills (Figure 13). One hole was drilled through 251 meters of sediment and 19 meters of basalt. The oldest sediment is latest Albian, at the sediment-basalt contact. The sediments here are predominantly detrital clays, moderate brown to grayish-brown in color, grading into coccolith detrital clays below about 238 meters. The concentration of zeolites increases to $25 \%$ downwards in the section. The basalt recovered is coarse-grained, olivine-poor, and glassy. From variations in grain size at least four flows were sampled, each one estimated to be 3-4 meters thick. The section is largely barren of microfossils. The upper 125.5 meters are Pliocene and younger based on a few foraminifera and radiolarians. Cretaceous radiolarians were found, both at 190 meters and with etched nannofossils at 218.5 meters. Below 238 meters, arenaceous and calcareous foraminifera and etched nannofossils of latest Albian age are common. The minimum basement age is 102 m.y., on the basis of the nannofossils. A lack of diversity in foraminiferal assemblages and the general nature of the nannofossils suggest a cold-water regime, and thus a more southerly latitude, in the Cretaceous. Sedimentation rates for the Pliocene to Recent and the Cretaceous must have been much higher than that in the condensed or dissolution facies between 125.5 and 190 meters.

\section{Site 257}

This site is located in 5278 meters of water in the southeast Wharton Basin in an area of abyssal hills (Figure 13). The hole was drilled through 262 meters of sediment and 64.5 meters of basalt. The oldest sediment is middle Albian, 13 meters above the basalt-sediment contact. From the sediment surface down to between 170 and 200 meters is a dark reddish-brown detrital clay, zeolite rich, or zeolite bearing. Below this and down to 249 meters is a reddish-brown to gray coccolith detrital clay to clayey coccolith ooze and chalk. Between this unit and the basalt is 13 meters of barren reddish-brown detrital clay. The contact with the basalt appears conformable. Seven or eight basalt flows were drilled which become fresher deeper into the hole. At the top of Core $15(298-307.5 \mathrm{~m}), 37$ meters into the basalt, a clay layer with consolidated graded sand and subrounded pebbles of basalt was recovered. Several lines of evidence suggest that this material is in situ and indicates an unconformity in the basalt section (discussed below). The site is largely barren of microfossils. Cretaceous radiolarians were found at 85.5-95 meters and middle Albian nannofossils and foraminifera were found below 199.5 meters. Only one species of planktonic foraminifera was seen, suggesting a cold-water environment for the middle Albian. The middle Albian is at least 50 meters thick, which implies a minimum sedimentation rate of about $25 \mathrm{~m} / \mathrm{m} . \mathrm{y}$. for this sequence. The entire Tertiary and Upper Cretaceous section is condensed to 75 meters and represents a dissolution facies.

\section{Discussion}

\section{Stratigraphy and Sedimentation}

Figure 17 shows the comparative stratigraphies of sites in the Wharton Basin from Legs 22, 26, and 27. Leg 26 and 22 sites are shown backtracked in Figure 8. In all, the stratigraphies are not greatly similar. A zeolitic clay facies predominates in the Southern Basin, but for sites farther north siliceous (fossiliferous) sediments have been deposited since about the Pliocene, possibly relfecting the movement of these sites north into more productive zones. The carbonate compensation depth has been quite shallow in the basin from the mid Cretaceous to about mid Tertiary (Figure 9). These data indicate a level between 3000 and 4000 meters, while present levels are believed to be about 4500 meters (Berger and Winterer, in press).

The most striking lithology in the basin is a dissolution facies or condensed series of zeolitic clays representing considerable portions of time. These facies may be centered about the Late Cretaceous, early Tertiary, and Oligocene, and are discussed in detail later.

A point common to all sites in the Wharton Basin is the very thick mid and Upper Cretaceous sections, particularly the Albian. This means very high sedimentation rates, say $20 \mathrm{~m} / \mathrm{m} . \mathrm{y}$. The same phenomenon is also found on the Ninetyeast Ridge (Figure 23). The reason for this is not immediately clear. However, because the Wharton Basin probably occupied a restricted area between India- Australia, and Antarctica in the Middle Cretaceous (see Figre 10), then it is likely that high detrital sediment accumulation rates would result.

\section{Crustal Ages and Tectonics}

The oldest sediment Leg 26 retrieved in the Wharton Basin is middle Albian at Site 257. At Site 259 to the east (Figure 13), Neocomian sediments were cored (Heirtzler, Veevers, et al., in press). The distribution of ages is confusing. Site 257 is near Site 256 in age and both are younger than Site 259. Site 257 could be older than middle Albian since the barren clay layer above the basalt obviously represents a significant but unknown time interval. Potassium-argon dating of the basalts showed that the upper basalt section is probably near 100 m.y. old (Rundle et al., this volume, Chapter 17) which agrees with the paleontologic estimates. However, below Core 14, K-Ar ages are $157 \pm 5$ and $177 \pm 9$ m.y. (275-16-2, 257B-17-5; op. cit.). This implies an intrabasalt hiatus of $50 \mathrm{~m} . \mathrm{y}$. or more. Several facts support this interpretation of an unconformity. A clay layer was found at the top of Core 15 and the seismic velocity is significantly higher below this level (Hyndman, this volume, Chapter 16). Although the K-Ar age estimates are believed reliable, we nonetheless treat them with circumspection, in view of the well-known difficulties associated with radiometric age determinations on deepsea tholeiitic basalts.

Despite the many uncertainties in the crustal ages at Wharton Basin sites, it is nonetheless clear that the age increases to the south in a systematic manner (Figure 


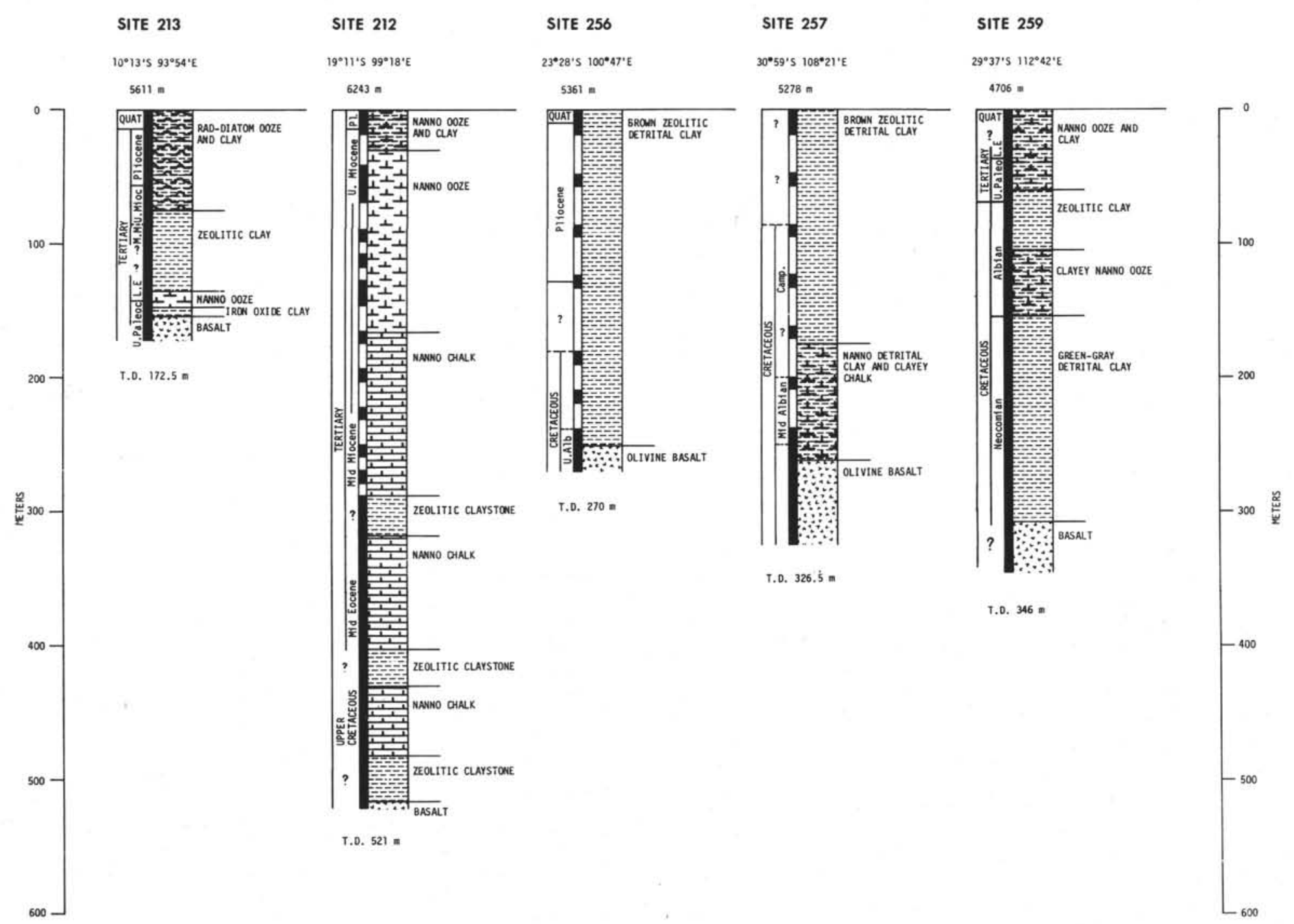

Figure 17. Stratigraphy of sites drilled in the Wharton Basin (see Figure 12 for locations). Data from von der Borch, Sclater, et al., 1974; Heirtzler, Veevers, et al., in press; and Leg 26. 


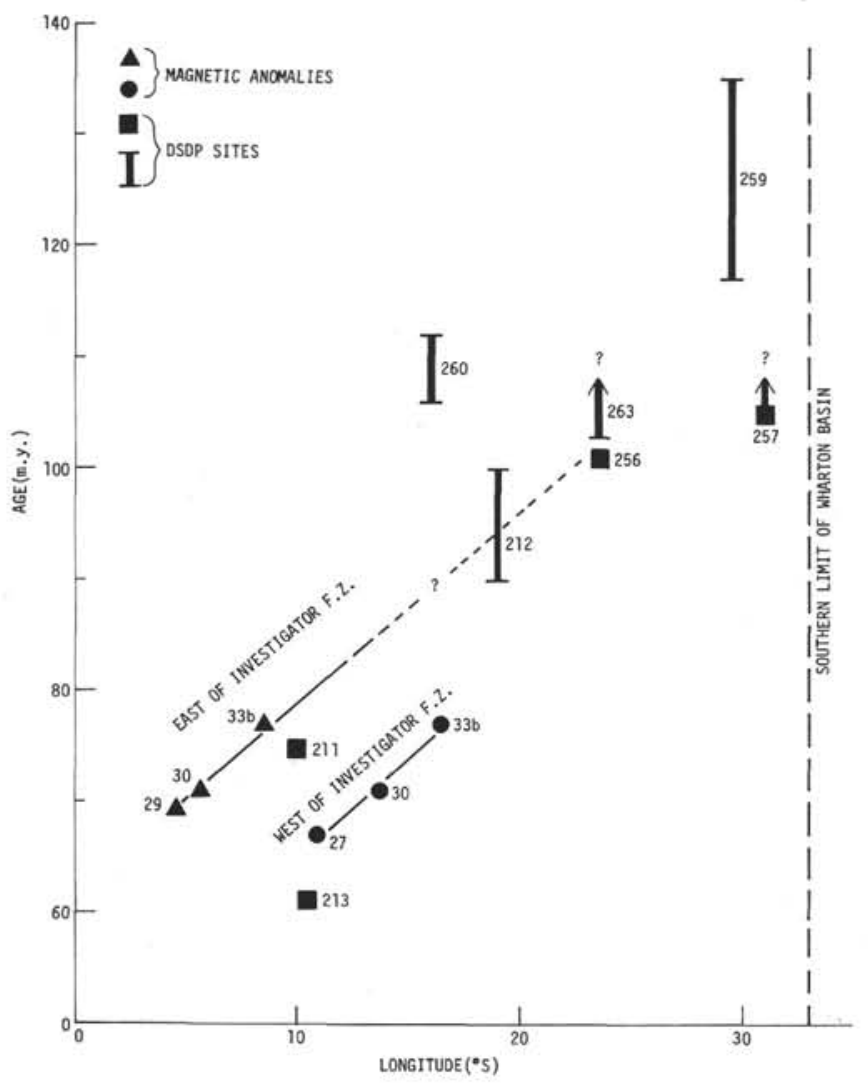

Figure 18. Crustal ages in the Wharton Basin. Data from DSDP sites Leg 22 (Sclater et al., 1974) and Leg 27 (Heirtzler, Veevers, et al., in press) and Leg 26, and from the identification of marine magnetic anomalies by Sclater and Fisher (1974).

18). This supports the suggestion that India was situated next to Antarctica in the original configuration of Gondwanaland and separated from it by north-south spreading. Sclater and Fisher (1974) have proposed a transform fault, the Investigator Fracture Zone, near $100^{\circ} \mathrm{E}$ in the Wharton Basin. This ancient transform runs north-south and has significant left-lateral offset. Several sites clearly lie east of the fracture. This includes $211,260,259$, and 257 (Figure 4). We have plotted the ages of magnetic anomalies identified on opposite sides of this fracture versus latitude in Figure 18. Also shown are DSDP sites versus latitude. Age spans for Sites 263 and 259 fall on a spreading rate line extrapolated from magnetic anomalies to the east of the Investigator Fracture Zone. Sites 211 and 257 fall below this line. The maximum age of the Wharton Basin in the south using this analysis is about 130 m.y., and Site 257 could be this old, which would support in a general sense the $\mathrm{K}-\mathrm{Ar}$ results.

It is not clear from the regional topography on which side of the Investigator Fracture Zone Sites 212 and 256 lie. If we accept the age estimate of Sclater et al. (1974) for 212 (shown in Figure 18), then it is clear that Site 212 lies on the east side. Similarly, Site 256 appears to lie to the east. Using a spreading curve extended through Site 256 gives a maximum age of 115 m.y. for the Wharton Basin. Site 260 appears anomalously old and suggests another left-lateral fracture zone east of the Investigator Zone.

The above analysis implies that there are no DSDP sites west of the Investigator Fracture Zone in the Wharton Basin except for Site 213. It also shows that Site 212 is about $95 \mathrm{~m} . \mathrm{y}$. old and that the spreading rate during the formation of the southern basin was around 6 $\mathrm{cm} / \mathrm{yr}$. It is possible that the $M$ sequence of magnetic anomalies (Larson and Pitman, 1972) may be found off southwest Australia.

\section{UNCONFORMITIES AND DISSOLUTION FACIES IN THE INDIAN OCEAN}

We have investigated the drilling results for Legs 22 through 27 (and part of 28) in order to determine regional significance of unconformities in the Indian Ocean. One possible interpretation of these data is the recognition of disconformities and/or pronounced dissolution units centered in the Oligocene, early Tertiary, and Late Cretaceous. The sources of our data have been the Initial Report volumes published or in press at the time of this writing (April 1974), and published Geotimes articles.

For our usage, the term unconformity refers to a significant gap (demonstrated or inferred) in the stratigraphic record (disconformity or paraconformity). The term dissolution facies refers to an interval completely barren of calcareous microfossils, usually with a lithology of detrital or pelagic clay accompanied by zeolites and other indicators of extremely slow sedimentation. Unconformities in this sense represent active erosion or complete nondeposition of sediment, while dissolution facies indicate slow deposition beneath the calcium carbonate compensation depth (CCD). Dissolution units have also been referred to as condensed sequences (LeClarie, in press). Dissolution units may or may not include unconformities but obviously this cannot be resolved due to the lack of stratigraphic control. We use the loose term hiatus to indicate unconformities (i.e., disconformities) and/or dissolution facies in a general sense.

The descriptions of unconformities from the results of some of the earlier legs of the drilling program have been somewhat equivocal because of the often large intervals between cores. Fortunately, in the Indian Ocean program continuous coring or instances of greater than $50 \%$ coring have been rather frequent. Accordingly, we have not felt compelled to restrict our definitions by taking into account coring intervals.

In Figure 19 sites in the western Indian Ocean are shown projected into a north-south line (locations in Figure 4). Unconformities and/or dissolution facies are shown centered on the Oligocene and the early Tertiary (or latest Cretaceous). The crust in the western Indian Ocean is generally young compared to the eastern basin, with most sites being no older than the latest Late Cretaceous. Consequently, a Late Cretaceous hiatus is not well defined on the west, as it is in the east (see below). In the western basin (Figure 19) true unconformities were encountered at Sites 249, 246, 239(?), 240, 


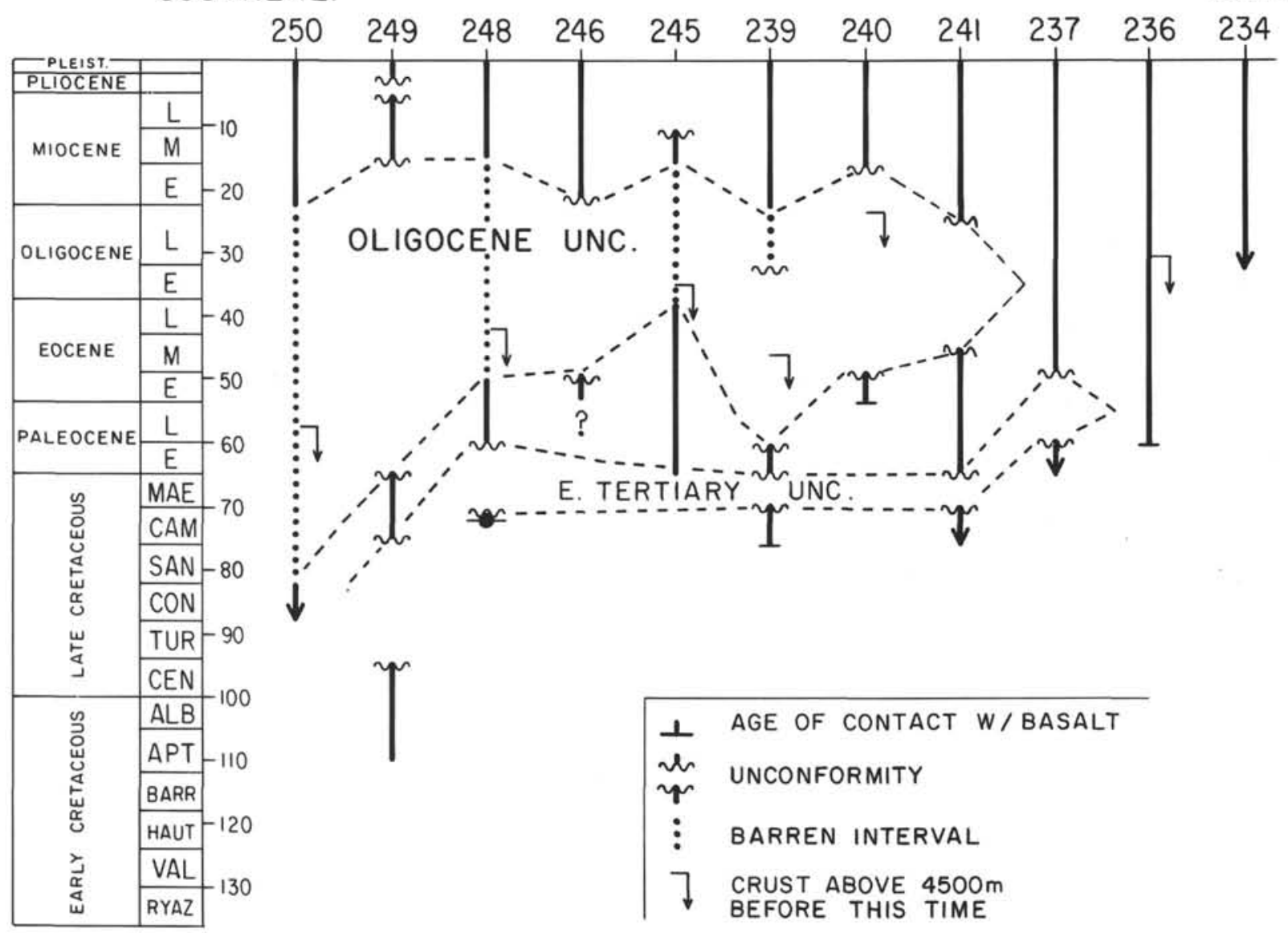

Figure 19. Unconformities and dissolution facies in the western Indian Ocean. Data from Fisher, Bunce, et al., 1972; Simpson, Schlich, et al., in press; and LeClaire, in press. The arrow pointing downwards on the side of some of the columns indicates the time at which the oceanic basement at the site subsided below 4500 meters according to the agedepth curves of Sclater et al., 1971. The present CCD in the Indian Ocean is at 4500 meters. Note how the dissolution facies apparently occur above this level at several sites and also that fossiliferous material occurs stratigraphically above the dissolution units, even though the sites were well below 4500 meters at these times.

and 241. Dissolution facies generally represented by zeolitic clay are equally common (see Site 250 , Chapter 3 ) although the early Tertiary hiatus appears to be expressed solely as a disconformity. Local unconformities are indicated since the late Miocene at Site 245 in the Madagascar Basin and in the Pliocene at Site 249 atop the Mozambique Plateau. The maximum duration of the Oligocene hiatus is from the Late Cretaceous to the early or middle Miocene. This indicates that the physical causes of the disconformities and dissolution facies ceased operating in the early/middle Miocene but could have been initiated at any time prior to this back to the Late Cretaceous. The cause of the early Tertiary hiatus persisted until at least the early Eocene.

The danger of regionalizing these observed hiatuses cannot be overemphasized, considering our imperfect knowledge of the history of the local sedimentation regimes at each site. Consideration of the paleobathymetry of the sites (see Figure 19 caption; also see previous sections, Figure 9) indicates that for those on normal oceanic crust the Oligocene hiatus was being formed when the sites were well below 4500 meters (the $\mathrm{CCD}$ for much of the present ocean; Berger and
Winterer, in press). For these sites (Sites 250, 248, 245, 239 [?]) this hiatus is often expressed as a dissolution facies, as would be expected for sedimentation below the CCD. However, both Sites 250 and 248 show very condensed sequences over the interpreted time span of the hiatus relative to the sequences above and below this level, suggesting that the dissolution units contain unconformities. For the sites on shallow structures (249, 246 ), which are still above the CCD and probably have always been, an Oligocene disconformity is found. The early Tertiary hiatus is found at sites that are shallow at present and appears to have formed at other sites when they were well above 4500 meters. Thus we can generalize that the cause of these unconformities is pervasive throughout the water column and that both shallow and deep sea floor were affected.

Data from sites in the eastern Indian Ocean are interpreted to show hiatuses centered on the Oligocene, early Tertiary, and Late Cretaceous (Figure 20). The upper limit of the Oligocene hiatus in Figure 20 is in the late Miocene or Pliocene, the upper limit of the early Tertiary hiatus in early Eocene, and the limit of the Cretaceous hiatus in the Campanian. 
WESTERLY

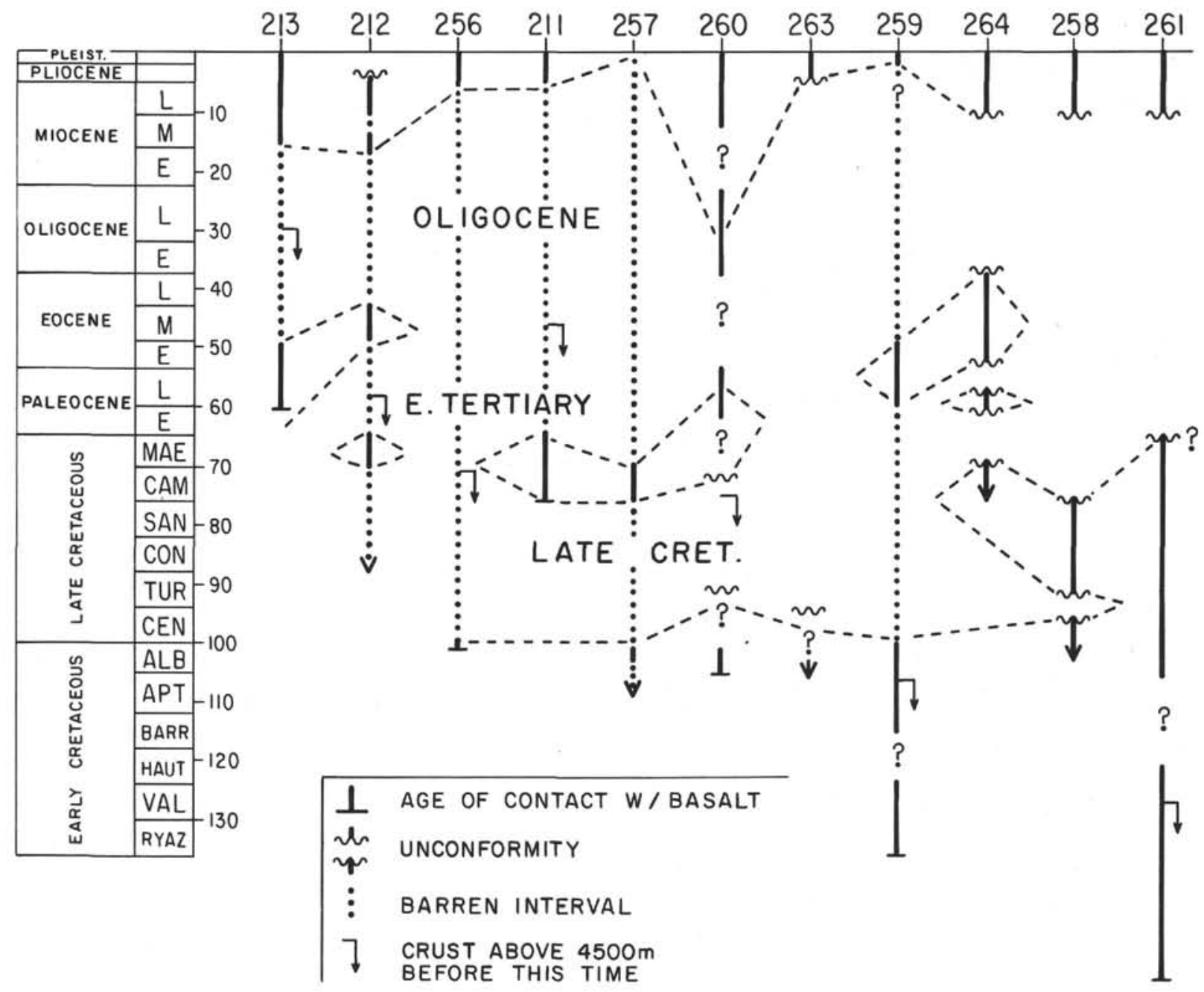

Figure 20. Unconformities and dissolution facies in the eastern Indian Ocean. Data from von der Borch, Sclater, et al., 1974; and Pimm, 1974; Heirtzler, Veevers, et al., in press; Hayes, Frakes, et al., 1973.

Unconformities are apparently only present in the shallow sites such as Sites 264 and 258 on the Naturaliste Plateau. Site 263 is an exception to this. Unconformities at Site 260 and 261 in the Late Cretaceous and Tertiary may be of local significance only since they represent the contact between overlying turbidites and subjacent pelagic deposits. Sites from Ninetyeast Ridge and Broken Ridge are not shown in Figure 20. On Ninetyeast Ridge early Oligocene and a small section of the upper Eocene is missing at Site 253, overlain by a much reduced lower Oligocene section (see discussion of Ninetyeast Ridge and Figure 9 above). The Oligocene unconformity at the northern sites on Ninetyeast Ridge is overlain by upper Oligocene sediments, and the Paleocene unconformity by the middle Eocene. On Broken Ridge (Site 255) the upper Eocene to lower Miocene is apparently missing and Campanian through lower Eocene rocks are absent above an angular unconformity. At the deeper sites dissolution facies, which may or may not include unconformities, are more common. The Oligocene dissolution facies formed below the 4500-meter level, while the earlier hiatuses formed at this level or above it. Again as in the west these dissolution facies represent condensed sequences.

As with the western sites, the eastern sites show hiatuses for the same general time periods at both shallow and deep sites with the shallow sites exhibiting in general, true unconformities. The hiatus centered on the Oligocene ends in the early/middle Miocene in the west and in the late Miocene/Pliocene in the east. On the Ninetyeast Ridge, the same hiatus ends in the late Oligocene, suggesting that if the same physical cause is responsible for both the shallow and deep hiatuses, it ceased functioning in the shallow regions first. The early Tertiary unconformity ends in the early Eocene in both the west and the east, but later, in the middle Eocene, on the Ninetyeast Ridge (Pimm, 1974). The Late Cretaceous hiatus is exhibited only in the east, except possibly for Site 249 on the Mozambique Ridge (Figure 18 ), and ends in the Campanian. In the east this hiatus is a true unconformity at the shallow sites.

In Figure 21 we have plotted Oligocene and older DSDP sites from Legs 21 through 28 on a late Oligocene tectonic reconstruction. The extent of the Oligocene 


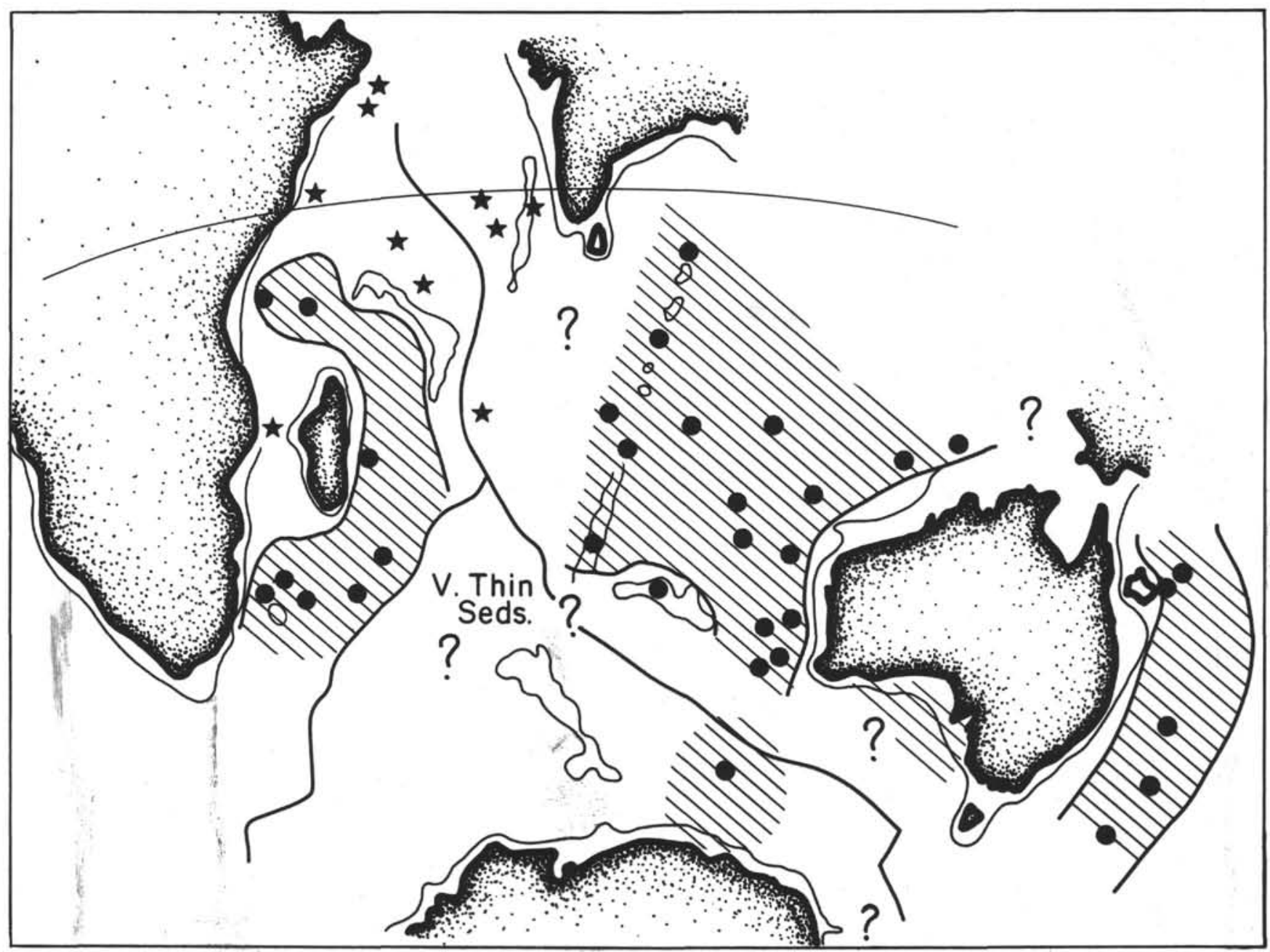

Figure 21. DSDP sites plotted on an Oligocene reconstruction for the Indian Ocean (modified from McKenzie and Sclater, 1971). Data from Figures 19 and 20 with additional DSDP data from Leg 23 (Whitmarsh, Weser, Ross, et al., 1974). Stars indicate sites where complete Oligocene section was recovered (apparent), solid circles are sites where parts of the Oligocene are missing from erosion or non deposition, or where the Oligocene is apparently within a dissolution unit. Shading indicates the extent of the Oligocene hiatus.

hiatus is indicated by the shaded regions. This Hiatus is present at both shallow and deep sites whereas a complete Oligocene section (apparent) was recovered in the northwest at sites near the paleoequator. Figure 21 shows that the western Pacific sites of Leg 21 exhibit the same hiatus. Kennet et al. (1972) described this hiatus as a disconformity found at various depths between about 1400 and 4500 meters. It apparently ends in the middle Miocene, about the same time as in the western Indian Ocean. Kennett et al. (1972) pointed out that Oligocene unconformities are also found in southern Australia, New Guinea, and parts of New Zealand (e.g., Brown et al., 1968; Davies and Smith, 1971; Hornibrook, 1966). Carter and Landis (1972) described the south Australia unconformity as a paraconformity below shelf limestones of early Miocene age. Oligocene hiatuses are not generally found in the central Pacific (Winterer, Ewing, et al., 1973). In the south central Pacific Leg 8 DSDP results show a disconformity near the late
Eocene/early Oligocene, but the Oligocene itself is marked by calcareous ooze with very high sedimentation rates (Tracey, Sutton, et al., 1971). High calcareous sedimentation was also seen in the Oligocene of Leg 3 DSDP in the South Atlantic (Maxwell et al., 1970), where the Oligocene is represented by two chalk ooze formations. Evidently, then, erosion and dissolution in Indian Ocean and southwest Pacific during the Oligocene was paralleled by high carbonate deposition in other southern oceans at the same time.

In Figure 22 we have plotted Indian Ocean and southwestern Pacific DSDP sites on an early Eocene reconstruction. In this diagram the open circles indicate where either the Oligocene hiatus was of such great extent as to eliminate any stratigraphic record of the early Tertiary hiatus, or where the oldest sediments retrieved were not older than Eocene. The early Tertiary hiatus is more difficult to regionalize because of these complications. However, certain patterns appear similar to 


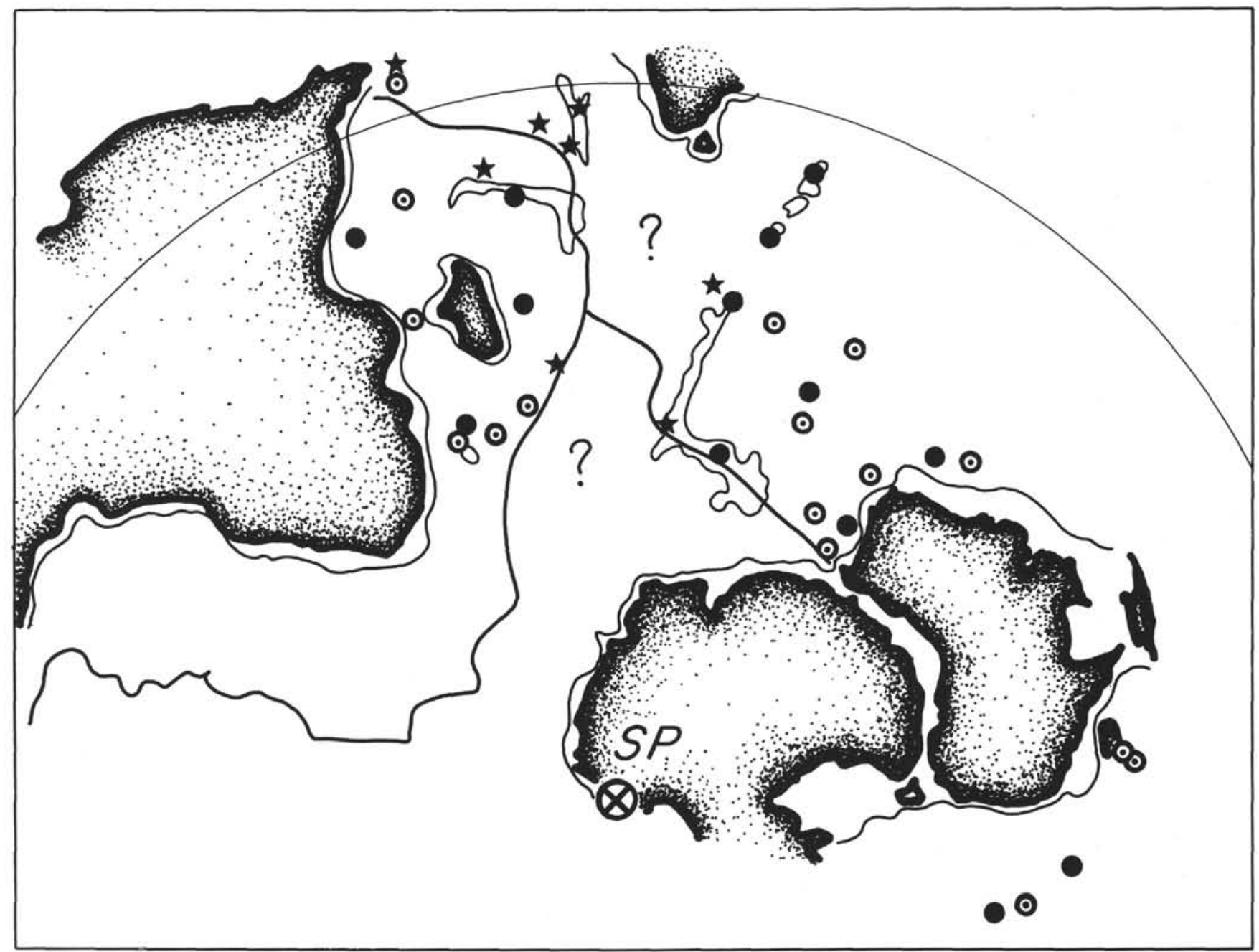

Figure 22. DSDP sites plotted on an early Eocene reconstruction for the Indian Ocean (from McKenzie and Sclater, 1971, figure 44). Data from Figures 19 and 20 with additional Leg 23 data from Whitmarsh, Weser, Ross, et al., 1974. The open circles here represent sites which either did not fully penetrate through the Eocene and Paleocene or where the suspected early Tertiary hiatus could not be separated from the lower limits of the Oligocene hiatus. Both hiatuses are believed to have similar regional distributions.

the Oligocene data (Figure 21), such as uninterrupted sedimentation in the northwest, unconformities on shallow structures such as the Ninetyeast Ridge, and a well-developed hiatus in southerly latitudes. The similarity in the regional patterns of the early Tertiary and Oligocene hiatuses implies that they may be due to similar causes. If this is true, then it can be suggested that the Oligocene hiatus may not be due to initiation of the Circumpolar Current, as suggested by Kennett et al. (1972) because the early Tertiary hiatus ended before this current was initiated.

The early Tertiary hiatus is documented in the central Pacific by Leg 17 results (Douglas et al., 1973). This hiatus is a disconformity which ends in the middle Eocene in both shallow $(2300 \mathrm{~m})$ and deep $(5400 \mathrm{~m})$ sites. The central Pacific hiatus ends at the same time as the early Tertiary hiatus on the Ninetyeast Ridge. Leg 21 results also show a hiatus ending in the middle Eocene in the southwest Pacific (Kennett et al., 1972). In the south Atlantic, the early Tertiary sequence is evidently complete (Maxwell et al., 1970).

Late Cretaceous sediments have not often been sampled by DSDP, but in the central Pacific some Leg 17 results indicate an unconformity ending in the Campanian as in the Indian Ocean.

It seems, therefore, that regional hiatuses in the Cretaceous and early Tertiary in the Indian Ocean are closely allied with contemporaneous ones in the central and southwest Pacific. The Oligocene hiatus in the Indian Ocean and southwest Pacific, however, occurred at the same time as high calcareous sedimentation in the central Pacific and south Atlantic.

Attempts to explain the cause or causes of these hiatuses must consider numerous variables, including tectonism and continental drift, world climate, oceanic productivity, and oceanic circulation, all of which are obviously interrelated in a complex way. We will limit our speculations to the Oligocene and early Tertiary 
hiatuses and admit beforehand to our trepidation in attempting to explain them.

The following observations might be considered facts regarding these hiatuses which require explanation:

1) Both hiatuses are expressed over a wide depth range.

2) Well-developed unconformities appear in the western Indian Ocean and southwest Pacific whereas dissolution facies, probably containing unconformities, are more common in the eastern Indian Ocean.

3) The early Tertiary and Oligocene hiatuses have similar regional extent in the Indian Ocean and southwest Pacific.

4) The Oligocene hiatus is not found in the central Pacific as is the early Tertiary hiatus.

5) The Oligocene unconformity in the Indian Ocean and southwest Pacific occurs in concert with high calcareous sedimentation rates in the south Atlantic and central Pacific.

In our discussion we employ the following model for hiatus formation in the deep sea. True unconformities are due to erosion or nondeposition caused by vigorous surface and/or deep ocean currents. The fact that the hiatuses in question cover such a wide depth range indicates that both deep and surface circulation have been involved. Dissolution facies are caused by solution of calcareous material below the CCD. The CCD is the level where carbonate solution by cold, undersaturated bottom waters equals carbonate supply from surface waters. The deep-sea CCD may be moved shallower by a decrease in regional productivity, removal of carbonate by precipitation on shelf areas, an increase in the amount and rate of supply of bottom waters, and an increase in the undersaturation of bottom waters (e.g., Berger and Winterer, in press).

Bottom water is formed in the Antarctic shelf regions and notably in the Ross and Weddell seas (see discussion in Heezen and Hollister, 1971). Ross Sea water is believed to flow east and west of the Tonga arc north into the Pacific. East of the arc it flows through a deep sill near the Samoan Islands into the central Pacific. Weddell Sea water in part flows east into the western regions of the Indian Ocean where it behaves as a western boundary undercurrent. Bottom water also drifts north through fracture zones in the Southeast Branch, where it may be joined by Ross Sea water flowing west between Australia and Antarctica, to pass through the gap between Naturaliste Plateau and Broken Ridge into the Wharton Basin (op. cit.). This pattern of circulation is similar to the regional development of the Oligocene hiatus and possibly the early Tertiary one also. It also explains why the hiatuses are more definitely expressed in the western ocean regions. Tectonic and climatic events in the Antarctic region are therefore important to consider in our discussion.

An important event in the Late Cretaceous was the rifting of New Zealand from Antarctica and the opening of the Ross Sea (Hayes and Ringis, 1973). Shortly after this, in the early Eocene or before, climatic deterioration and glacial conditions occurred in Antarctica (Margolis and Kennett, 1970). This combination of events led to the formation of substantial amounts of "aggressive," erosive Antarctic Bottom Water. Ross Sea water entered the central and southwest Pacific to erode and dissolve sediments. Weddell Sea water had similar effects in the western Indian Ocean and spread through the gap between Broken Ridge and Naturaliste Plateau into the Wharton Basin. Surface circulation was intensified as a result of climatic cooling and probable increased storminess. Surface productivity and faunal diversity were also decreasing during this period. Figure 23 shows sedimentation rates in the Indian Ocean Basin and points out the general trend of implied decrease in productivity. Decrease in sedimentation served to enhance shoaling of the CCD and promoted the formation of dissolution facies.

A similar story can be constructed for the Oligocene hiatus. Climate deterioration and late Oligocene glaciation are probable for Antarctica (Margolis and Kennett, 1970). Low productivity is also indicated (Figure 23). It is curious that the Oligocene hiatus is not found in the central Pacific. Oligocene erosion is found in the Samoan gap, the bottom water conduit to the central Pacific (D. A. Johnson, personal communication). Removal of great quantities of carbonate from the Indian Ocean and southwest Pacific in the Oligocene has resulted in high carbonate sedimentation elsewhere in the Pacific and Atlantic-thus possibly answering the question of where is material went.

Between the late early Eocene and the middle of the Oligocene, climatic conditions in Antarctica were probably a little warmer (Margolis and Kennett, 1970). This was probably sufficient to reduce the supply of Antarctic Bottom Water and diminish the intensity of current activity to the point where sedimentation could resume. The Oligocene hiatus was brought to a close by the gradual establishment of the present pattern of circum-Antarctic flow sometime around the end of the Oligocene (Kennett, Houtz, et al., 1973), once again reducing the influence of Antarctic Bottom Water to inhibit sedimentation in the ocean basins farther north. Although initial spreading between Australia and Antarctica commenced late in the early Eocene (Weissel and Hayes, 1972), development of the circum-Antarctic current did not occur until the later part of the Oligocene when final rifting occurred south of the South Tasman Rise (Kennett, Houtz, et al., 1973).

We have attempted to attribute these unconformities to climatic events in Antarctica. This explanation is incomplete in several respects. First, it is not entirely clear what Antarctic Bottom Water circulation is today, much less 60 m.y. ago. Paleobathymetry models would be helpful in this regard. Second, it is equally vague what effect Antarctic glaciation had on ocean surface water movements. These currents have probably contributed to forming the hiatuses at shallow sites. We would also recommend experimental and analytical study of these currents considering continental dispersion and paleowinds (e.g., Luyendyk et al., 1972).

\section{SEDIMENTATION THROUGH TIME}

In the preceding sections of this paper we have discussed in some detail the geologic history of four regions of the southern Indian Ocean and the pattern of regional 


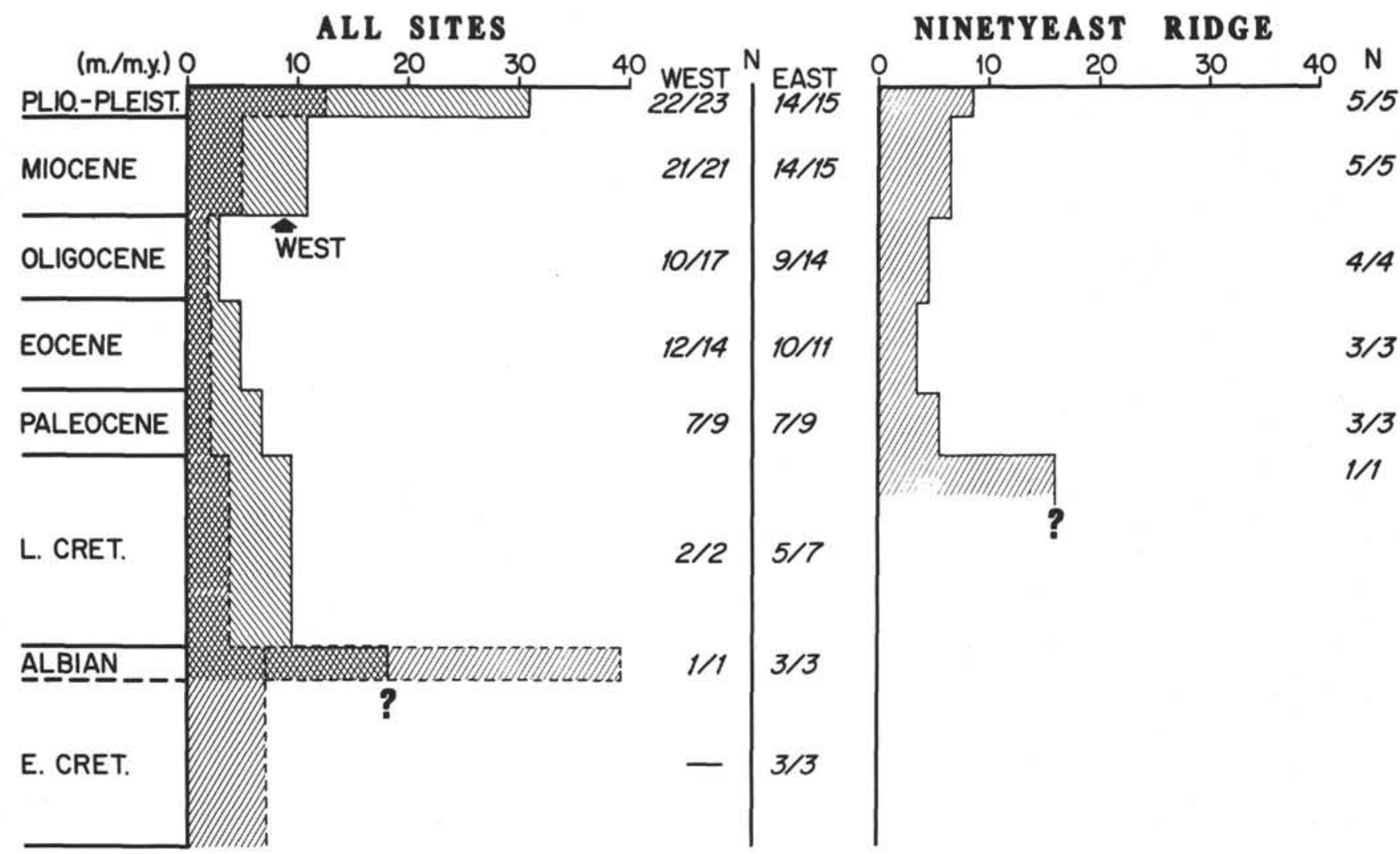

Figure 23. Sedimentation rates in the Indian Ocean. Fractions to the sides of the figure indicate the number of sites where section was recovered over the number of sites it was anticipated. Average sedimentation rate is total section divided by number of sites anticipated. Note the very high Albian rates.

unconformities observed. In this concluding section, we briefly summarize the changing patterns of sedimentation in the Indian Ocean through time. Four time periods will be considered: Late Cretaceous, middle Eocene, early Oligocene, and present day.

\section{Cretaceous Sedimentation}

Little is known of Early Cretaceous sedimentation in the western Indian Ocean. We know from drilling results on Legs 26 and 27 that the eastern basin was a region of quiet, deep-water clay accumulation. There was probably volcanic activity along the line of incipient rifting marked by Broken Ridge and the Naturaliste Plateau. Volcanic rocks are found in the Perth Basin (Brown et al., 1968), and on the Naturaliste Plateau (Site 258) detrital sediments composed of the weathering products of basaltic volcanic rocks were accumulating.

Figure 24 shows the situation towards the end of the Cretaceous. At this time India, Ninetyeast Ridge, Broken Ridge, and the Naturaliste Plateau formed a topographic barrier effectively dividing the newly forming Indian Ocean into two parts, a closed basin in the east and a western basin with open connections with the south Atlantic to the west and the Tethyan region to the north. Although this barrier must have had a profound effect on ocean circulation patterns, the sediments deposited in the eastern and western basins at this time do not appear markedly different. The south end of Ninetyeast Ridge (Site 216) was the site of accumulation of shallow-water sediments and volcanic ashes, presumably reflecting ongoing volcanic activity at the south end of the ridge. Similarly the south side of Naturaliste Plateau was accumulating coarse volcaniclastic conglomerates. The northern part of Naturaliste Plateau, Broken Ridge, and the northern part of Ninetyeast Ridge formed shallow-water platforms not more than a few hundred meters deep where pelagic carbonates quietly accumulated. In the deeper waters of the Wharton Basin sedimentation was either very slow or nonexistent. The sedimentary record at all Wharton Basin sites consists only of very thin unfossiliferous clays.

In the western basin terrigenous sediments were accumulating off the northern coast of East Africa but elsewhere the only sediments observed are the thin, unfossiliferous clays of the Mascarene and Mozambique basins. It seems likely that carbonate sediments were accumulating along the shallow western margin of India and around Madagascar but we have no evidence of this. At this time the carbonate compensation depth in 


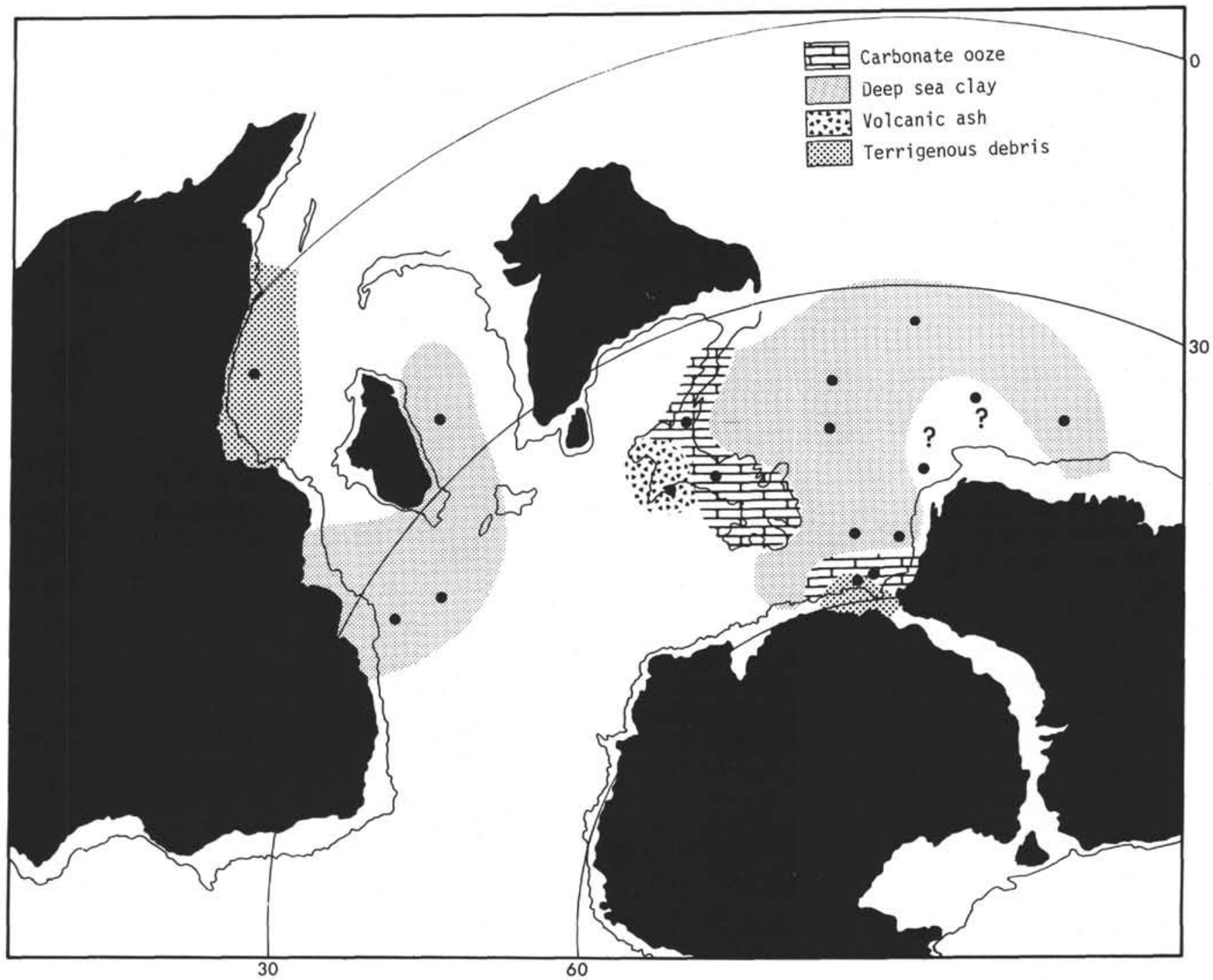

Figure 24. Late Cretaceous sedimentation plotted on a paleogeographic reconstruction for 75 m.y.B.P. (from McKenzie and Sclater, 1971). Solid circles represent Deep Sea Drilling Project sites which sample this time interval.

both western and eastern basins seems to have been significantly shallower than its present-day depth (Figures 6 and 9).

\section{Middle Eocene Sedimentation}

Figure 25 shows the distribution of middle Eocene sediments. Circulation between eastern and western basins was still restricted by Ninetyeast Ridge and Broken Ridge. At this time we must assume that Broken Ridge was exposed above sea level since the oldest sediments found overlying the Cretaceous limestones at Site 255 are upper Eocene littoral gravels. Volcanic activity was proceeding at the southern end of Ninetyeast Ridge with a great thickness of volcanic ashes accumulating in very shallow water at Site 253 . On the Naturaliste Plateau, the northern quiescent end of Ninetyeast Ridge and, around the submerged margins of Broken Ridge, pelagic carbonate sedimentation proceeded uninterrupted. In view of the record at Site
264 it seems likely that Eocene sediments were deposited at Site 258 and subsequently removed by erosion rather than their not having been deposited.

Carbonate sediments were also accumulating at this time on the Chagos-Laccadive and Mascarene plateaus and in the area northwest of them, and terrigenous debris continued to be deposited off the northern coast of East Africa. The Wharton Basin, the Central Indian Basin, and the Madagascar and Mozambique basins were areas of nondeposition or of very slow accumulation of deep-sea clays. In the Somali Basin (Site 240), the northern part of the Mascarene Basin (Site 239), the western Mozambique Basin (Site 248), and on the Mozambique (Site 249) and Madagascar (Site 246/247) ridges, the middle Eocene is not represented at all. It seems likely that in these regions the Eocene sediments were very thin and have been subsequently removed at the time of formation of the Oligocene unconformity discussed in the preceding section, rather than their not having been deposited at all. 


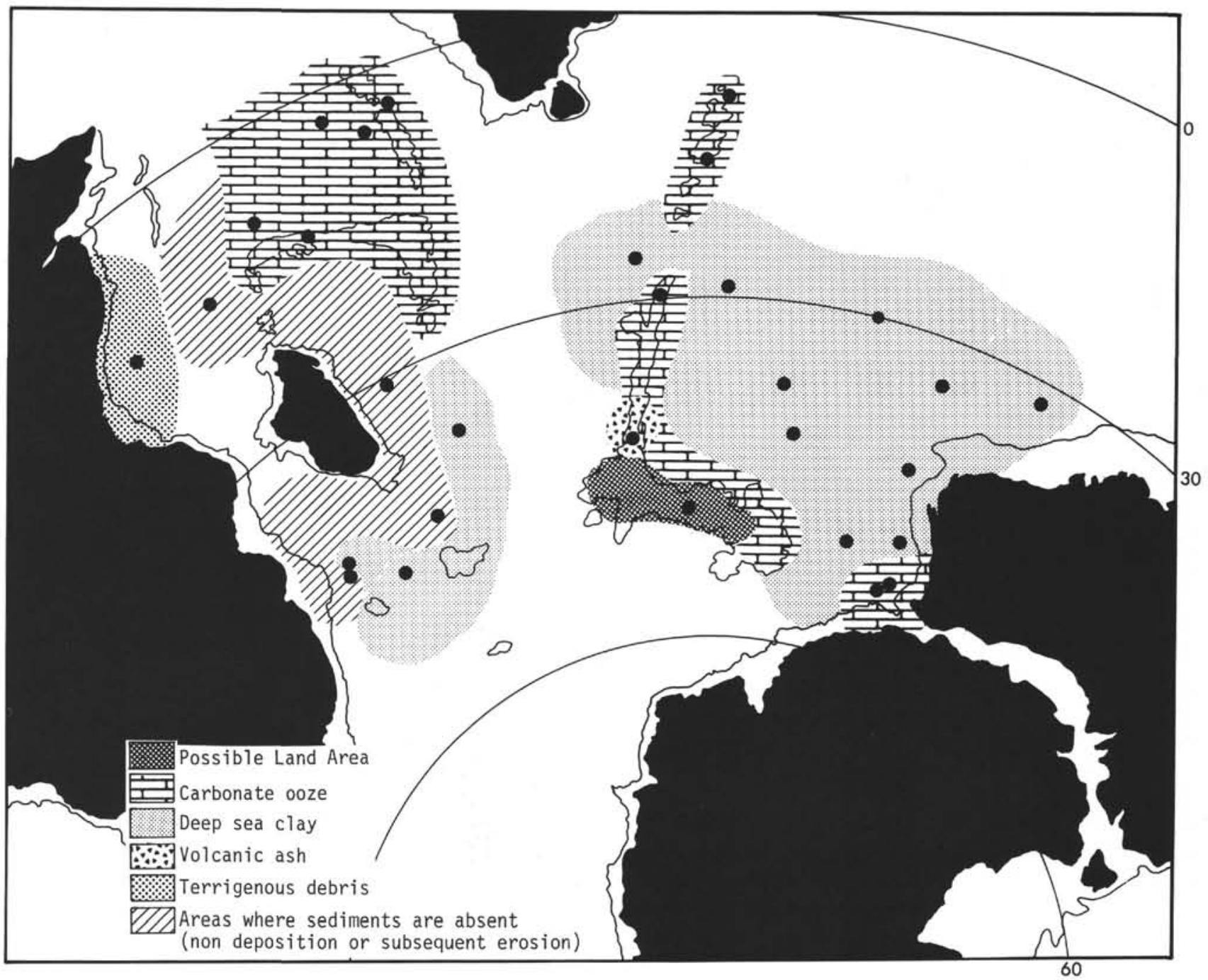

Figure 25. Middle Eocene sedimentation plotted on a paleogeographic reconstruction for 45 m.y.B.P. (from McKenzie and Sclater, 1971). Solid circles represent Deep Sea Drilling Project sites which sampled this time interval.

\section{Early Oligocene Sedimentation}

By early Oligocene the geography of the Indian Ocean region more closely resembled that of today (Figure 26). There was a clear, though narrow, circumpolar passage around the Antarctic continent, and communication around and through Ninetyeast Ridge between the Wharton Basin and the Central Indian Basin. In the south Broken Ridge and Kerguelen Plateau had begun to separate. In the northwest the passage between India and Arabia connecting Tethys to the western basin was becoming constricted. The mid-ocean ridge system in its present configuration was becoming active.

Unfortunately, the Oligocene sedimentary record is poorly represented because of the regional Oligocene unconformity discussed in the preceding section; however, some observations can be made. Volcanic activity, probably subaerial, was proceeding at the south end of Ninetyeast Ridge resulting in the accumulation of detrital volcanic sands and silts in an essentially lagoonal or littoral environment at Site 254. Elsewhere on Ninetyeast Ridge and probably Broken Ridge and
Kerguelen Plateau pelagic carbonate sediments were accumulating sporadically in water depths of a few hundred meters. All the sections are incomplete. Pelagic carbonate sediments were also accumulating in the strait between Madagascar and the mainland of Africa and on the Chagos-Laccadive and Mascarene plateaus and in the region north of them. Terrigenous sediment continued to pile up off northern east coast of Africa and south of Arabia. Oligocene sediments are missing from the Naturaliste Plateau, from large areas of the Wharton Basin, and from the entire deep-water region west of the Central Indian Ridge and north of the Southwest Branch.

\section{Present-Day Sedimentation}

Figure 27 shows the pattern of present-day sedimentation. Thick terrigenous sediments are accumulating on the Indus Cone, Ganges Fan, and Zambezi Fan, but accumulation of such sediments off the Somali coast has ceased. Carbonate sediments are accumulating in the shallow areas along the Australian and African coast, on the shallow ridges and platforms, and in the 


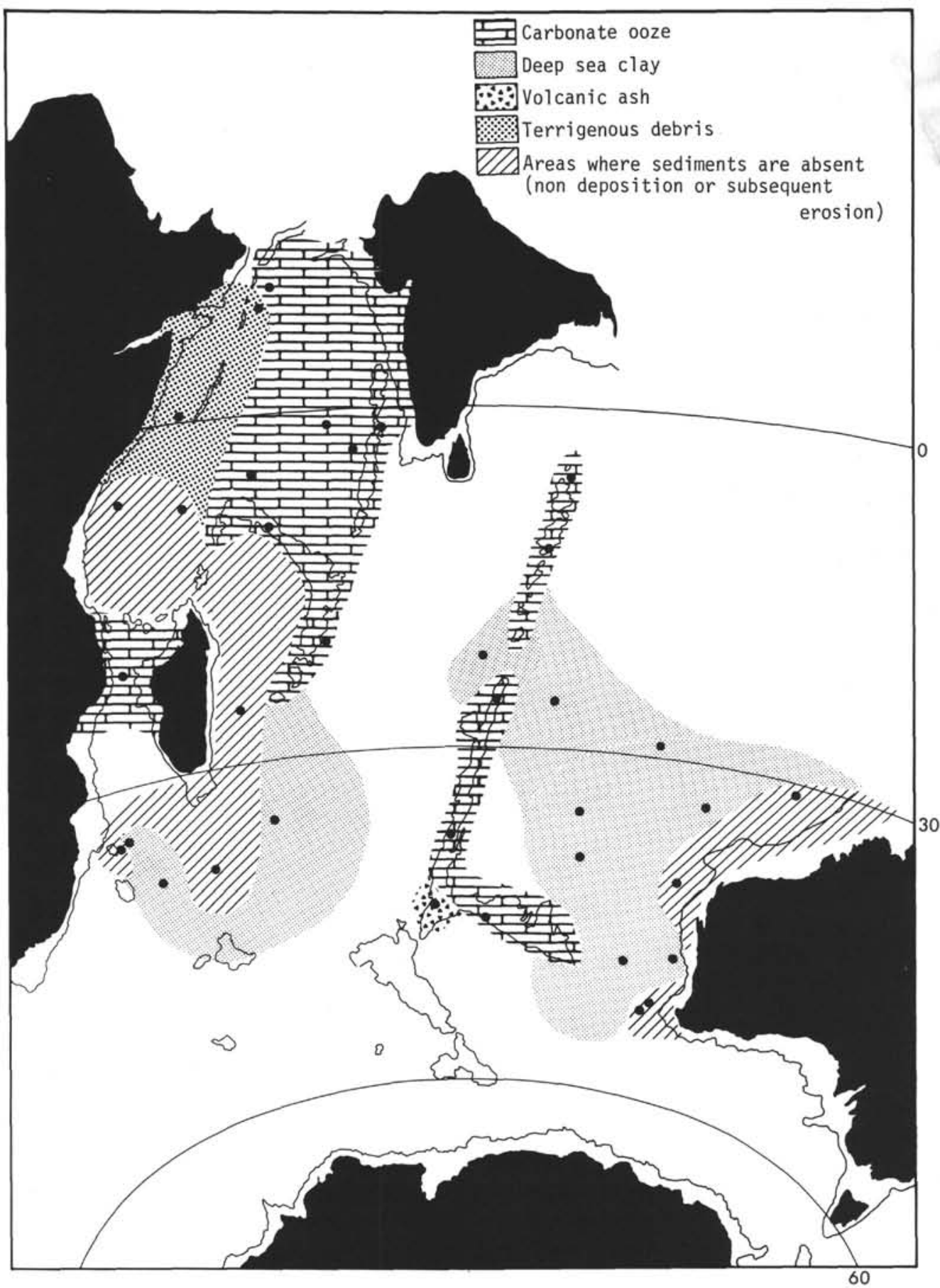

Figure 26. Early Oligocene sedimentation plotted on a paleogeographic reconstruction for 36 m.y.B.P. (from McKenzie and Sclater, 1971). Solid circles represent Deep Sea Drilling Project sites which samples this time interval.

shallower parts of the Somali Basin. Siliceous sediments are found in significant amounts in the Crozet Basin to the south and in the equatorial regions of the deep basins. Elsewhere deep-sea clays are quietly accumulating except in the central Wharton Basin (Site
212) and southern Mascarene Basin (Site 245) where sedimentation appears to have stopped. The proportion of terrigenous detrital debris accumulating in the Mozambique and Mascarene basins appears to be much higher than in the Central Indian and Wharton basins. 


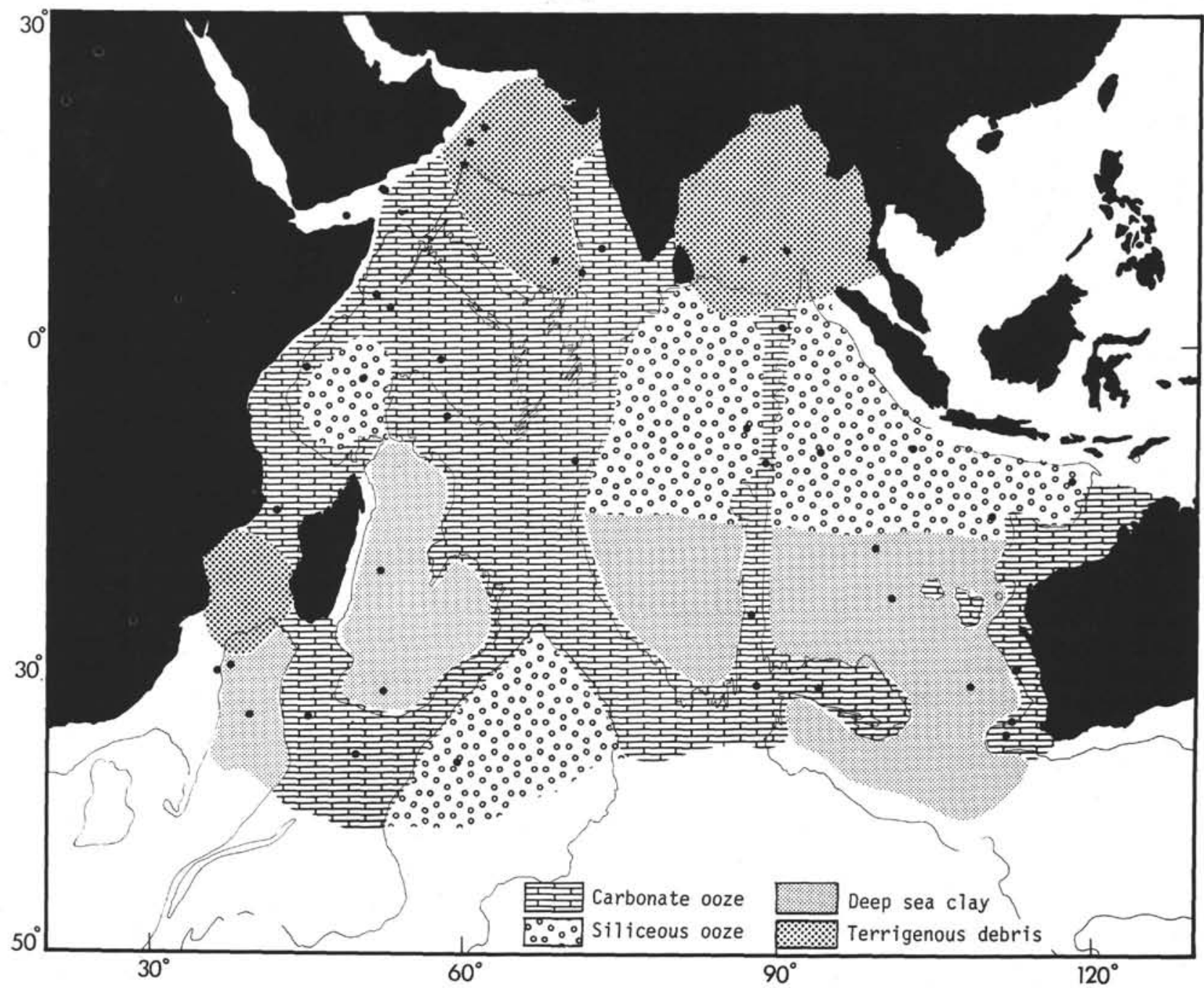

Figure 27. Present-day sedimentation in the Indian Ocean. Solid circles represent Deep Sea Drilling Project sites.

\section{ACKNOWLEDGMENTS}

We would like to emphasize that in compiling this review we have drawn heavily upon the work of our colleagues, the shipboard scientists of Leg 26 and other Deep Sea Drilling Project cruises in the Indian Ocean. The data and many of the ideas expressed here are the result of their careful work, both at sea and subsequently at their home laboratories, and we apologize for any omissions or misinterpretations which may have crept in.

W. H. Berger, R. B. Kidd, and T. L. Vallier kindly reviewed the manuscript and made many helpful suggestions for improvement. Special thanks are given to Mary A. Young for her patient assistance in all phases of assembling this paper.

The Deep Sea Drilling Project is supported by the National Science Foundation under contract NSF C-482 with the University of California. The senior author was supported by Office of Naval Research Grant ONR CO-241.

\section{REFERENCES}

Baranzangi, M. and Dorman, J., 1969. World seismicity maps compiled from ESSA Coast and Geodetic Survey epicenter data: Seism. Soc. Am. Bull., v. 59, p. 369.

Berg, H. W., 1971. Sea floor spreading in the southwest Indian Ocean: J. Geophys. Res., v. 76, p. 6276-6282.
Berger, W. H. and von Rad, U., 1972. Cretaceous and Cenozoic sediments from the Atlantic Ocean. In Hayes, D. E., Pimm, A. C., et al., Initial Reports of the Deep Sea Drilling Project, Volume 14: Washington (U.S. Government Printing Office), p. 787-954.

Berger, W. H. and Winterer, E. L., in press. Plate stratigraphy and the fluctuating carbonate line. In Hsu, K. J. and Teulsyns, H. (Eds.), Pelagic sediments on land and in the ocean: symposium, Zurich, Sept. 1973.

Bowin, C. O., 1973. The origin of the Ninetyeast Ridge from studies near the equator: J. Geophys. Res., v. 78, p. 60296043.

Brown, D. A., Campbell, K. S. W., and Crook, K. A. W., 1968. The geological evolution of Australia and New Zealand: London (Pergamon).

Carter, R. M. and Landis, C. A., 1972. Correlative Oligocene unconformities in southern Australia: Nature, v. 237, p. 1213.

Crawford, A. R., 1969. India, Ceylon and Pakastan: new age data and comparisons with Australia: Nature, v. 223, p. 380-383.

Curray, J. R. and Moore, D. G., 1971. Growth of the Bengal deep-sea fan and denudation of the Himalays: Geol. Soc. Am. Bull., v. 82, p. 565-572. 
Davies, H. L. and Smith, I. E., 1971. Geology of eastern Papua. Geol. Soc. Am. Bull., v. 82, p. 3299-3312.

Dietz, R. S. and Holden, J. C., 1971. Pre-Mesozoic oceanic crust in the Eastern Indian Ocean (Wharton Basin): Nature, v. 229 , p. 307-312.

Douglas, R. G., Roth, P. H., and Moore, T. C., 1973. Biostratigraphic synthesis: Hiatuses and unconformities. In Winterer, E. L., Ewing, J., et al., Initial Reports of the Deep Sea Drilling Project, Volume 17: Washington (U.S. Government Printing Office), p. 905-909.

DuToit, A. L., 1937. Our wandering continents: Edinburgh and Landar (Oliver and Boyd).

Ewing, J. and Hollister, C. D., 1972. Regional aspects of Deep Sea Drilling in the western North Atlantic. In Hollister, C. D., Ewing, J., et al., Initial Reports of the Deep Sea Drilling Project, Volume 11: Washington (U.S. Government Printing Office), p. 951-973.

Ewing, M., Eittreim, S., Truchan, M., and Ewing, J. I., 1969. Sediment distribution in the Indian Ocean: Deep-Sea Res. v. 16, p. 231-248.

Fisher, R. L., Bunce, E. T., et al., 1972. Deep Sea Drilling Project in Dodo Land-Leg 24: Geotimes, v. 17, p. 17-21.

Flores, G., 1970. Suggested origin of the Mozambique Channel: Geol. Soc. South Africa Trans, v. 73, p. 1-16.

Francis, T. F. G. and Raitt, R. W., 1967. Seismic refraction measurements in the southern Indian Ocean: J. Geophys. Res., v. 27, p. 3015-3042.

Hayes, D. E., Frakes, L. A., et al., 1973. Leg 28 deep sea drilling in the southern ocean: Geotimes, v. 18, p. 1924.

Hayes, D. C., and Ringis, J., 1973. Sea floor spreading in the Tasman Sea: Nature, v. 243 , p. $454-458$.

Heezen, B. C. and Hollister, C. D., 1971. The face of the deep: New York (Oxford University Press).

Heezen, B. C. and Tharp, M., 1965. Tectonic fabric of the Atlantic and Indian Oceans and continental drift: Phil. Trans. Roy. Soc. London, v. 258, p. 90-106.

Heirtzler, J. R., Veevers, J., et al., in press. Initial Reports of the Deep Sea Drilling Project, Volume 27: Washington (U.S. Government Printing Office).

Hornibrook, N. de B., 1966. The stratigraphy of Landon (or Boundary) Creek, Oanaru: New Zealand J. Geol. Geophys., v. 9, p. 458.

Kennett, J. P., Burns, R. E., Andrews, J. E., Churkin, M., Davies, T. A., Dumitrica, P., Edwards, A. R., Galehouse, J.' S., Packham, G. H., and van der Lingen, G. J., 1972. Australian-Antarctic continental drift, paleocirculation changes and Oligocene deep-sea erosion: Nature Phys. Sci., v. 239 , p. $51-55$.

Kennett, J. P., Houtz, R. E., et al., 1973. Deep sea drilling in the roaring forties: Geotimes, v. 18, p. 14-17.

King, L., 1962. Morphology of the Earth: New York (Hafner).

Larson, R. L. and Pitman, W. C., III, 1972. World-wide correlations of Mesozoic magnetic anomalies; and its implications: Geol. Soc. Am. Bull., v. 83, p. 3645-3662.

Laughton, A. S., Matthews, D. H., and Fisher, R. L., 1971. The structure of the Indian Ocean. In Maxwell, A. E. (Ed.), The sea, v. 4, Part II: New York (John Wiley), p. 543-586.

LeClaire, L., in press. Late Cretaceous and Cenozoic pelagic deposits-Paleoenvironment and paleoceanography of the central western Indian Ocean. In Simpson, E., Schlich, R., et al., Initial Reports of the Deep Sea Drilling Project, Volume 25: Washington (U.S. Government Printing Office).

Luyendyk, B. P., Forsyth, D., and Phillips. J. D., 1972. Experimental approach to the paleocirculation of the oceanic surface waters: Geol. Soc. Am. Bull., v. 83, p. 2649-2664.

Margolis, S. V. and Kennett, J. P., 1970. Antarctic glaciation during the Tertiary recorded in sub-Antarctic deep-sea cores: Science, v. 170, p. 1085-1087.
Maxwell, A. E., von Herzen, R. P., Hsu, K. J., Andrews, J. E., Saito, T., Percival, S. F., Milow, E. D., Boyce, R. E., 1970. Deep Sea drilling in the South Atlantic: Science, v. 168, p. 1047-1058.

McElhinney, M. W., 1970. Formation of the Indian Ocean: Nature, v. 228, p. 977-979.

McKenzie, D. P. and Sclater, J. G., 1971. The evolution of the Indian Ocean since the Late Cretaceous: Geophys. J. Roy. Astron. Soc., v. 25, p. 437-528.

Morgan, W. J., 1972. Deep mantle convection plumes and plate motions: Am. Assoc. Petrol. Geol. Bull., v. 56, p. 203213.

Pimm, A. C., 1974. Sedimentology and history of the northeastern Indian Ocean from the Late Cretaceous to Recent. In von der Borch, C., Sclater, J., et al., Initial Reports of the Deep Sea Drilling Project, Volume 22: Washington (U.S. Government Printing Office).

Sclater, J. C. and Fisher, R., 1974. The evolution of the east central Indian Ocean, with emphasis on the tectonic setting of the Ninetyeast Ridge. Geol. Soc. Am. Bull., v. 85, p. 683702 .

Sclater, J., Anderson, R., and Bell, L., 1971. The elevation of ridges and the evolution of the central eastern Pacific: J. Geophys. Res., v. 76, p. 7888-7915.

Sclater, J. G., von der Borch, C., Veevers, J. J., Hekinian, R., Thompson, R. W., Pimm, A. C., McGowran, B., Gartner, S., Jr., Johnson, D. A., 1974. Regional synthesis of the deep sea drilling results from Leg 22 in the eastern Indian Ocean. In von der Borch, C., Sclater, J., et al., Initial Reports of the Deep Sea Drilling Project, Volume 22: Washington (U.S. Government Printing Office), p. 815-831.

Schlich, R., in press. Sea floor spreading history and deep sea drilling results in Madagascar and Mascarene basins, western Indian Ocean. In Simpson, E., Schlich, R., et al., Initial Reports of the Deep Sea Drilling Project, Volume 25: Washington (U.S. Government Printing Office), p. 663678.

Schlich, R. and Patrait, P., 1968. Interpretation possible de donnes geophysique recueillies sur la dorsale medioindienne entre 20 et $40^{\circ}$ sud: C. R. Acad. Sci., Paris, v. 266, p. $820-822$.

1971. Mise en evidence d'anomalies magnetiques axiales sur la branch ouest de la dorsale medio-indienne: $\mathrm{C}$. R. Acad. Sci., Paris, v. 272, p. 700-703.

Simpson, E., Schlich, R., et al., in press. Initial Reports of the Deep Sea Drilling Project, Volume 25: Washington (U.S. Government Printing Office).

Tracey, J. I., Sutton, G. H., et al., 1971. Initial Reports of the Deep Sea Drilling Project, Volume 8: Washington (U.S. Government Printing Office).

Veevers, J. J., Jones, J. G., and Talent, J. A., 1971. IndoAustralian stratigraphy and the configuration and dispersal of Gondwanaland: Nature, v. 229, p. 383-388.

von der Borch, C., Sclater, J., et al., 1974. Initial Reports of the Deep Sea Drilling Project, Volume 22: Washington (U.S. Government Printing Office).

Watkins, N. D., Gunn, B. M., Nougier, J., and Baksi, A. K., 1974. Kerguelen: continental fragment or oceanic island? Am. Bull. Geol. Soc., v. 85, p. 201-212.

Weissel, J. and Hayes, D. E., 1971. Asymmetric sea floor spreading south of Australia: Nature, v. 231, p. 518-522.

Whitmarsh, R., Weser, O., Ross, D. A., et al., 1974. Initial Reports of the Deep Sea Drilling Project, Volume 23: Washington (U.S. Government Printing Office).

Winterer, E. L., Ewing, J., et al., 1973. Initial Reports of the Deep Sea Drilling Project, Volume 17: Washington (U.S. Government Printing Office). 